\title{
Direct Electron Transfer-Type Bioelectrocatalysis of Redox Enzymes at Nanostructured Electrodes
}

\author{
Taiki Adachi, Yuki Kitazumi *, Osamu Shirai ${ }^{-1}$ and Kenji Kano *(i) \\ Division of Applied Life Sciences, Graduate School of Agriculture, Kyoto University, Sakyo, Kyoto 606-8502, \\ Japan; adachi.taiki.62s@st.kyoto-u.ac.jp (T.A.); shiraio@kais.kyoto-u.ac.jp (O.S.) \\ * Correspondence: kitazumi.yuki.7u@kyoto-u.ac.jp (Y.K.); kano.kenji.5z@kyoto-u.ac.jp (K.K.); \\ Fax.: +81-75-753-6456 (Y.K. \& K.K.)
}

Received: 3 February 2020; Accepted: 13 February 2020; Published: 15 February 2020

\begin{abstract}
Direct electron transfer (DET)-type bioelectrocatalysis, which couples the electrode reactions and catalytic functions of redox enzymes without any redox mediator, is one of the most intriguing subjects that has been studied over the past few decades in the field of bioelectrochemistry. In order to realize the DET-type bioelectrocatalysis and improve the performance, nanostructures of the electrode surface have to be carefully tuned for each enzyme. In addition, enzymes can also be tuned by the protein engineering approach for the DET-type reaction. This review summarizes the recent progresses in this field of the research while considering the importance of nanostructure of electrodes as well as redox enzymes. This review also describes the basic concepts and theoretical aspects of DET-type bioelectrocatalysis, the significance of nanostructures as scaffolds for DET-type reactions, protein engineering approaches for DET-type reactions, and concepts and facts of bidirectional DET-type reactions from a cross-disciplinary viewpoint.
\end{abstract}

Keywords: direct electron transfer-type bioelectrocatalysis; nanostructures; mesoporous electrodes; curvature effect; protein engineering; bidirectional bioelectrocatalysis

\section{Introduction}

Electron transfer reactions in living organisms including photosynthesis and metabolisms play a central role in all living systems. Such biological electron transfer reactions are catalyzed by a variety of redox enzymes in high speed, high selectivity, and high specificity. Over the last four decades, redox enzymes have received much attention for use in the form of the coupling of enzymatic reactions with electrochemical reactions. The coupled reaction is called bioelectrocatalysis [1-11]. The coupling provides a variety of biological redox functions to conventional electrode materials and will open new ways for a wealth of fundamental researches and developing bioelectrochemical devices relating to biosensors [12,13], biological fuel cells $[2,4,6,8,9]$, bioelectrochemical reactors $[10,14]$, and biosupercapacitors [15].

Most redox enzymatic reactions can be coupled with electrode reactions via (artificial) redox compounds (called redox mediators) that shuttle electrons between enzymes and electrodes. This reaction is known as mediated electron transfer (MET)-type bioelectrocatalysis. Some redox enzymes can directly communicate with electrodes in the catalytic reaction. Such reactions are referred to as direct electron transfer (DET)-type bioelectrocatalyses (Figure 1). This type of the coupling makes it possible to develop more simple systems that can minimize thermodynamic overpotentials in well-organized couplings. However, DET-type enzymes providing clear bioelectrocatalytic waves are few, and DET-type reactions proceed only on suitably arranged electrode surfaces. This is because redox enzymes are large, and the redox sites in many redox enzymes are deeply buried in the enzyme matrix and electrically insulated throughout the entire enzyme volume. 


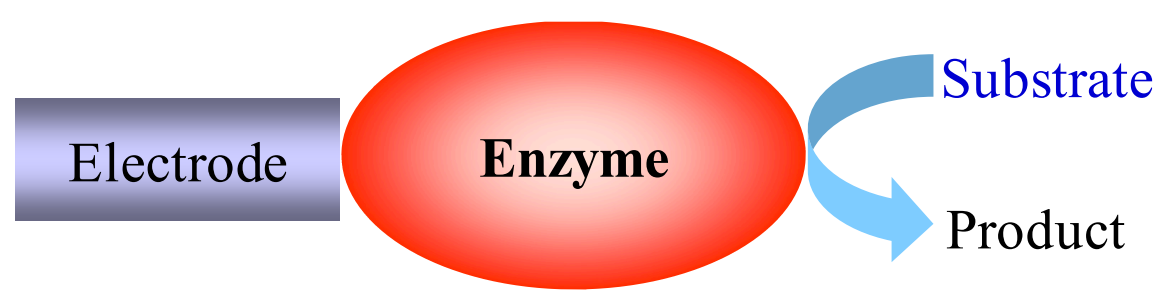

Figure 1. Schematic view of direct electron transfer (DET)-type bioelectrocatalysis.

Recent progresses in this field increased the sophistication in approaches to the assembly of electrode surfaces, tuning of electrode surfaces, and protein mutations to facilitate electron transfer reactions. On the other hand, in order to interpret bioelectrocatalytic waves, rigid analysis based on analytical equations on suitable models of DET-type reactions is required in relation to the thermodynamics and kinetics of bioelectrocatalyses (that is, electroenzymatic reactions) in view of the interfacial and intramolecular electron transfers and the structure of redox enzymes.

In this review, from a cross-disciplinary viewpoint, we will describe the basic concepts and theoretical aspects of DET-type bioelectrocatalysis, the significance of nanostructures as scaffolds for DET-type reactions, protein engineering approaches for DET-type reactions, and concepts and facts of bidirectional DET-type reactions.

\section{Theoretical Aspects for the DET-Type Bioelectrocatalysis}

The simplest reaction scheme for a substrate oxidation by DET-type bioelectrocatalysis is expressed by Equations (1) and (2).

$$
\mathrm{S}+\mathrm{E}_{\mathrm{O}} \stackrel{k_{\mathrm{c}}}{\rightarrow} \mathrm{P}+\mathrm{E}_{\mathrm{R}}
$$

and the electrode reaction:

$$
\mathrm{E}_{\mathrm{R}} \underset{k_{\mathrm{b}}}{\stackrel{k_{\mathrm{f}}}{\rightleftarrows}} \mathrm{E}_{\mathrm{O}}+n_{\mathrm{E}} \mathrm{e}^{-},
$$

where $E_{R}$ and $E_{O}$ are reduced and oxidized forms of an enzyme, respectively; $S$ and $P$ are its substrate and product, respectively; and $n_{\mathrm{E}}$ is the number of electrons of the enzyme. Parameters $k_{\mathrm{f}}, k_{\mathrm{b}}$, and $k_{\mathrm{c}}$ correspond to the rate constants of the forward electrode reaction, the reverse electrode reaction, and the enzymatic reaction, respectively. Under steady-state conditions (defined by $\partial c_{i} / \partial t=0$ ) without the concentration polarization of the substrate, the steady-state catalytic current $\left(i_{\mathrm{s}}\right)$ is given as Equation (3) [16]:

$$
i_{\mathrm{s}}=\frac{i_{\mathrm{s}}^{\lim }}{1+\frac{k_{\mathrm{c}}}{k_{\mathrm{f}}}+\frac{k_{\mathrm{b}}}{k_{\mathrm{f}}}},
$$

where $i_{\mathrm{s}}^{\mathrm{lim}}$ is the limiting steady-state current of the system at $k_{\mathrm{c}}<<k_{\mathrm{f}}$ and $k_{\mathrm{b}}<<k_{\mathrm{f}}$ and is given by a Michaelis-Menten-type equation (Equation (4)):

$$
\frac{i_{\mathrm{s}} \lim }{n_{\mathrm{E}} F A}=\frac{v_{\mathrm{E}} k_{\mathrm{c}} \Gamma_{\mathrm{E}}}{1+\frac{K_{\mathrm{S}}}{c_{\mathrm{S}}^{*}}} .
$$

The electrode kinetics are given by Butler-Volmer equation for substrate oxidation (Equations (5) and (6)):

$$
k_{\mathrm{f}}=k^{\circ} \exp \left\{\frac{(1-\alpha) n_{\mathrm{E}}^{\prime}}{R T}\left(E-E_{\mathrm{E}}^{\mathrm{o}^{\prime}}\right)\right\}
$$

and

$$
k_{\mathrm{b}}=k^{\circ} \exp \left\{-\frac{\alpha n_{\mathrm{E}}^{\prime} F}{R T}\left(E-E_{\mathrm{E}}^{\mathrm{o}^{\prime}}\right)\right\} \text {. }
$$


In these equations, $v_{\mathrm{E}}\left(=n_{\mathrm{S}} / n_{\mathrm{E}}\right)$ is the ratio of the stoichiometric number of the substrate against that of the enzyme ( $n_{\mathrm{S}}$ being the number of electrons of the substrate), $K_{\mathrm{S}}$ is the Michaelis constant of the substrate, $\Gamma_{\mathrm{E}}$ is the surface concentration of the adsorbed enzyme, $c_{\mathrm{S}}^{*}$ is the substrate concentration in the bulk phase, $k^{\circ}$ is the standard rate constant of the rate-limiting step of heterogeneous electron transfer, $n^{\prime}{ }_{\mathrm{E}}$ is the number of electrons in the rate-determining step of the heterogeneous electron transfer (usually $n_{\mathrm{E}}^{\prime}=1$ ), and $E_{\mathrm{E}}^{\mathrm{o}^{\prime}}$ is the formal potential of the electrode-active redox center in the enzyme.

The situation in which $i_{\mathrm{s}}=i_{\mathrm{s}}$ lim can be realized at $E \gg E_{\mathrm{E}}^{\mathrm{o}^{\prime}}$ for substrate oxidation in theory. However, it is often difficult to observe such potential-independent regions to give $i_{\mathrm{s}}$ lim within the potential windows of practical measurements. The large size of enzymes, eccentric location of the electrode-active redox center, and the random orientation of the enzymes are the major causes of such experimental observations. In DET-type reactions, the distance between an electrode and an electrode-active redox center in an enzyme $(d)$ is a critical value, because the electron transfer reaction rate constant should be dominated by the distance from the electrode. The rate constant of a long-range electron transfer reaction exponentially depends on $d$ as given by Equation (7) [17]:

$$
k^{\circ}=k_{\max }^{\mathrm{o}} \exp (-\beta d),
$$

where $k_{\max }^{\mathrm{o}}$ is the rate constant at the closest approach $\left(d=d_{\min }\right)$ and $\beta$ is the decay coefficient. Since the orientation of an adsorbed enzyme obviously affects $d$, the orientation of the adsorbed enzyme at the electrode is crucial for DET-type bioelectrocatalyses.

Herein, we demonstrate a simple orientation model, which is based on the random orientation of enzymes at a planar electrode. Figure 2 shows a schematic of the model, which assumes a spherical enzyme. In the enzyme, the electrode-active redox center locates at $d$ from the electrode. When the orientation of the enzyme is random on the planar electrode, the electrode-active redox center in the enzyme is located at the distance between $d_{\min }$ and the farthest approach $\left(d=d_{\max }\right)$ with a constant probability [18-20].

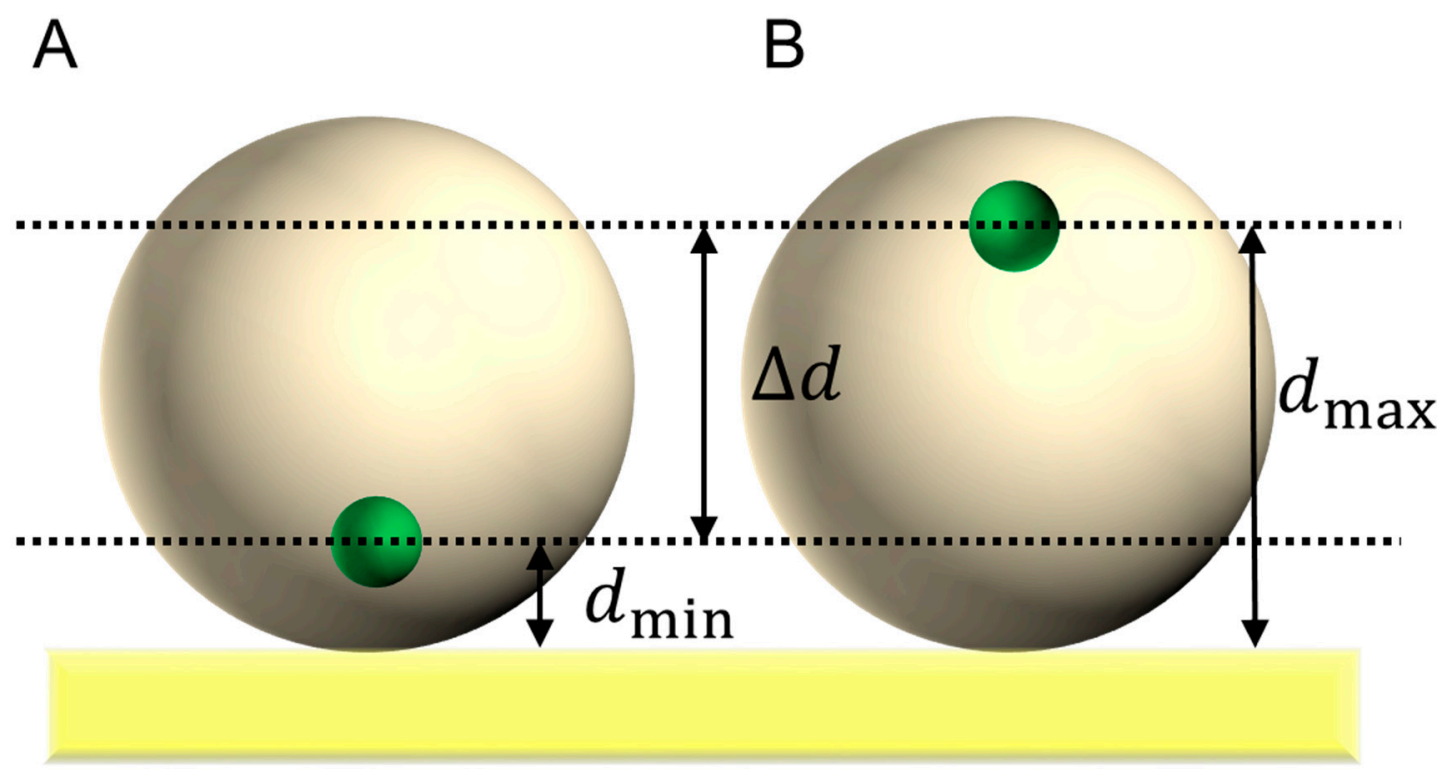

Figure 2. Schematic model of an adsorbed spherical enzyme on a planar electrode in (A) the closest approach of the electrode-active redox center in an enzyme (small spheres) and (B) the farthest approach of the electrode-active redox center. 
According to this model, the steady-state DET-type catalytic current by the randomly adsorbed enzyme is expressed by Equation (8):

$$
i_{\mathrm{s}}=\frac{i_{\mathrm{s}}}{2 \beta \Delta d\left(1+\eta^{-1}\right)} \ln \left|\frac{\frac{k_{\mathrm{c}}}{k^{0} \eta^{1-\alpha}}+\left(1+\eta^{-1}\right) \exp \left(-\beta d_{\min }\right)}{\frac{k_{\mathrm{c}}}{k^{0} \eta^{1-\alpha}}+\left(1+\eta^{-1}\right) \exp \left(-\beta d_{\max }\right)}\right|,
$$

where $\eta$ is the Nernst equation for the rate-determining step of the heterogeneous electron transfer (Equation (9)):

$$
\eta=\exp \left(\frac{n_{\mathrm{E}}^{\prime} F\left(E-E_{\mathrm{E}}^{\mathrm{o}^{\prime}}\right)}{R T}\right) .
$$

When the electrode surface has a porous structure, the concave surface inside the pore seems to be effective to the electron transfer kinetics. Figure 3 shows a schematic image of a decrease in the distance between the redox center in the enzyme and the electrode surface provided by a porous structure on the electrode [20]. According to the porous model, when the radius of a pore $\left(R_{\mathrm{p}}\right)$ is equal to the radius of the enzyme $\left(R_{\text {enz }}\right)$, the efficiency of the DET-type bioelectrocatalysis becomes maximum, and the orientation effect disappears in theory.

\section{A}

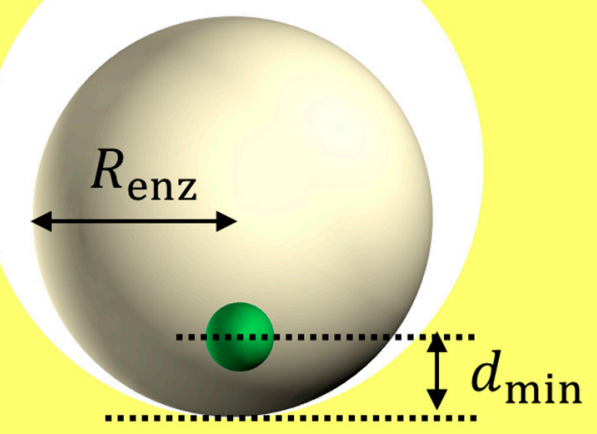

B

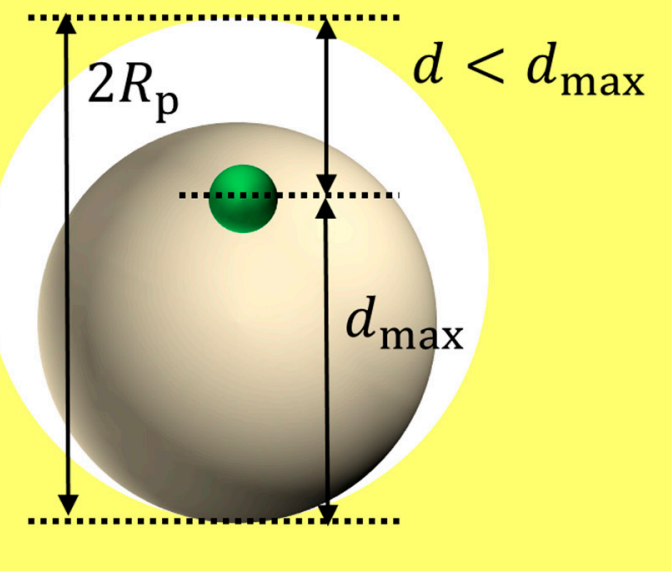

Figure 3. Schematic model of an adsorbed spherical enzyme with a radius of $R_{\mathrm{enz}}$ in a micropore with a radius of $R_{\mathrm{p}}$ on electrodes. (A) and (B) show the closest and farthest approaches of the redox center (small spheres), respectively.

The theoretical model enables calculating voltammograms for DET-type bioelectrocatalyses. Two examples of calculated voltammograms are given in Figure 4. The solid line corresponds to a steady-state voltammogram calculated for a DET-type bioelectrocatalysis of spherical enzymes adsorbed at a planar electrode. The voltammogram at the planar electrode shows an exponentially increasing region, a linearly increasing region, and a limiting current region. In the exponentially increasing region, fast electron transfer reactions predominantly occur between the electrode and the enzymes with orientations suitable for the DET-type bioelectrocatalysis. In the linearly increasing region, poorly and randomly oriented enzymes contribute the catalytic current; the exponentially decayed $k^{\circ}$ with an increase in $d$ (Equation (7)) of the poorly oriented enzymes is canceled with an exponential acceleration of $k_{\mathrm{f}}$ with an increase in $E$ for substrate oxidation (Equation (5)) as given by Equation (10):

$$
k_{\mathrm{f}}=k_{\max }^{\mathrm{o}} \exp \left\{\frac{(1-\alpha) n_{\mathrm{E}}^{\prime}}{R T}\left(E-E_{\mathrm{E}}^{\mathrm{o}^{\prime}}\right)-\beta d\right\} .
$$


The linearly increasing region is called the residual slope [18], which is frequently observed in voltammograms of DET-type bioelectrocatalyses. The current in the limiting current region is controlled by the enzymatic reaction by all of the effective enzymes adsorbed on the electrode; the current in the limiting current region is given by Equation (4). Therefore, the observation of the limiting current is very helpful and important for the theoretical analysis of steady-state catalytic waves of DET-type bioelectrocatalyses.

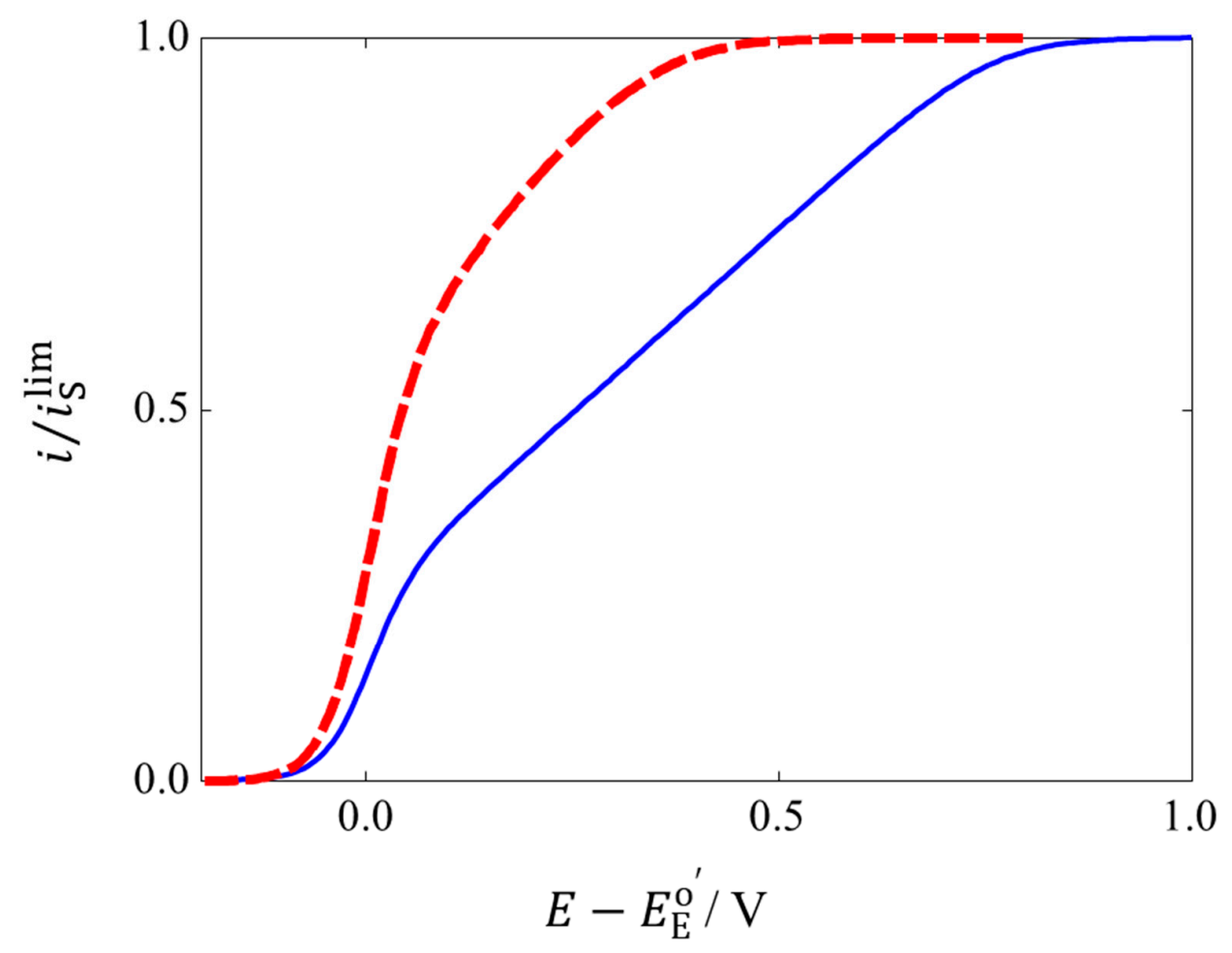

Figure 4. Steady-state bioelectrocatalytic voltammograms calculated for planar (solid line) and porous electrodes (dashed line). The parameters used are $d_{\min }=1.6 \mathrm{~nm}, d_{\max }=2.6 \mathrm{~nm}, R_{\mathrm{enz}}=2 \mathrm{~nm}$, $k_{\mathrm{c}} / k_{\max }^{\mathrm{o}}=10^{-10}$, and $R_{\mathrm{p}}=2.7 \mathrm{~nm}$.

However, it would be frequently difficult to observe such limiting regions in DET-type bioelectrocatalytic waves [18]. According to the random orientation model, the appearance of the residual slope region in steady-state catalytic waves indicates the existence of randomly oriented enzymes on the electrode surface. Based on this concept, elimination of the contribution by the randomly and unsuitably oriented enzymes from the voltammogram by subtracting the residual slope seems to be a reasonable approach to analyze the contribution from productively (or suitably) oriented enzymes [21,22].

A voltammogram of a DET-type bioelectrocatalysis by enzymes in the spherical pore electrode is shown as a dashed line in Figure 4. The value of the limiting steady-state current on the spherical model is identical with that calculated for the random orientation model on the planar electrode, because the calculations were performed for an identical amount of adsorbed enzymes (per electrochemically effective area) in the two models. However, the steady-state catalytic current on the spherical model is higher than that on the planar model except for the limiting region. Especially, the exponentially increasing region is enlarged, and the width of the residual slope region becomes narrow on the spherical model. Such changes in the steady-state wave indicate a drastic increase in $k^{\circ}$ of the enzymes located in the mesopore. This may be called a curvature effect of mesoporous electrodes for the DET-type bioelectrocatalysis. However, the precise relationship between the curvature of mesoporous electrodes and the efficiency of the DET-type bioelectrocatalysis seems to be complicated for actual 
cases, because the pore size distribution on porous electrodes will be unclear. Examples of DET-type bioelectrocatalyses at electrodes with controlled structures are introduced in the following section.

\section{Significance of Nanostructures of Electrodes for DET-Type Bioelectrocatalysis}

There are very few systematic investigations on the effects of nanostructures of electrodes on the DET-type bioelectrocatalysis, since the control of nanostructures on the electrode surface is difficult and will be one of our future challenges. However, techniques to construct nanostructures at carbon and gold materials have been relatively well examined (related references are given in the following detailed issues). The chemical state on the surface of these materials can be controlled. In this section, some outlines for DET-type bioelectrocatalyses on structure-controlled porous carbon and gold materials are introduced.

\subsection{Porous Carbon Electrodes}

Activated carbons have complex and irregular structures in the materials (Figure 5A). Therefore, such porous carbon materials are frequently characterized in terms of the pore-size distribution and the effective surface area. Systematic syntheses of porous carbon materials are reviewed by many researchers [23-25]. Although the effects of nanostructures on DET-type bioelectrocatalyses seem to be difficult to clearly understand, few works were published in systematic investigation on the effects of the pore size on the DET-type bioelectrocatalysis. Recently, a technique was developed to control the size of macropores and mesopores in carbon materials by magnesium oxide $(\mathrm{MgO})$ particles as templates (Figure 5B) [26,27]. MgO-templated carbons showed interesting properties as scaffolds for redox enzymes. DET-type bioelectrocatalyses at some porous carbon materials are shown as examples in this section.
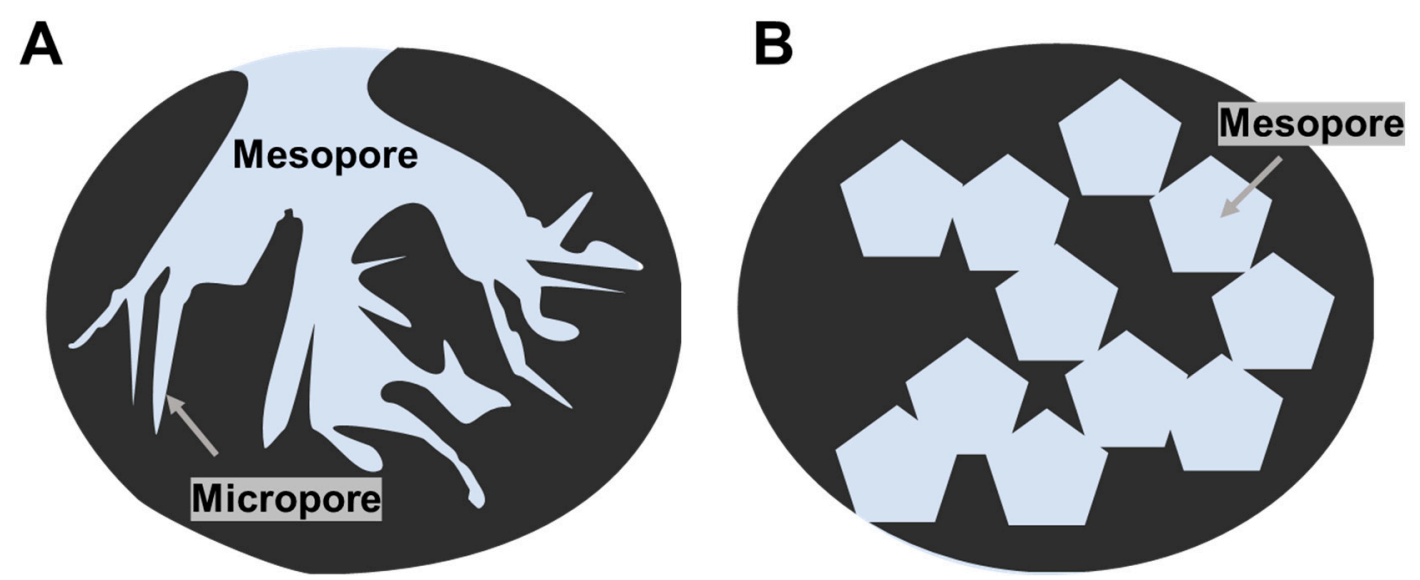

Figure 5. Schematic images of (A) typical activated-carbon and (B) MgO-templated carbon.

\subsubsection{Fructose Dehydrogenase}

Membrane-bound D-fructose dehydrogenase (FDH) is one DET-type redox enzyme [28]. FDH is a heterotrimer with a molecular mass of $138 \mathrm{kDa}$ that is composed of three subunits; subunit I $(67 \mathrm{kDa})$ contains a covalently bound flavin adenine dinucleotide (FAD) and oxidizes D-fructose to 5-keto-D-fructose, subunit II ( $51 \mathrm{kDa}$ ) includes three hemes $c$ (heme $1 c, 2 c$, and $3 c$ from the $\mathrm{N}$-terminus), and subunit III (20 kDa) exhibits a chaperonic function [29]. Carbon cryogels (CCGs) with various pore sizes were systematically synthesized as electrode materials. [30] The adsorption and desorption isotherms of nitrogen gas on the CCGs indicated that the materials had the pores with radiuses of 5, 11, 16, 16, 26, and $40 \mathrm{~nm}$. Although the Brunauer-Emmett-Taller (BET) surface areas of the CCG-modified electrodes were almost the same as each other, the oxidative catalytic current by the adsorbed FDH strongly depended on the pore size of the CCGs. The increase in the pore size resulted in an increase in the amount of FDH loaded on the electrode surface. The large pore seems to be 
convenient for FDH to penetrate the porous structure. Unfortunately, the steady-state catalytic waves of the DET-type bioelectrocatalysis of FDH depended on the electrode potential in the whole potential region examined; each wave had a residual slope without a limiting current region. The characteristics indicate that FDH molecules adsorb in a wide range of orientation patterns (random orientation) on the CCG electrodes. The surface modification of the porous carbon electrode with methoxy substituent-containing compounds was effective to improve the orientation of FDH [31]. Not the electrostatic interaction but the chemical interaction seems to affect the orientation of FDH; the enzyme has a specific interaction with the methoxy substituent of ubiquinones [32].

$\mathrm{MgO}$-templated carbons with various pore sizes were investigated as scaffolds of a DET-type bioelectrocatalysis of FDH [33]. The sizes of the mesopores studied were in the range from 10 to $100 \mathrm{~nm}$. This study showed that porous materials with a large radius were significant for the penetration of the enzyme into the porous electrode material. On the other hand, porous materials with a small radius that was comparable to that of the enzyme enhanced the thermal stability of the adsorbed enzyme. The limitation of the enzyme mobility seems to improve the stability. The fine-tuning of the pore-size distribution and the size of the interconnection between the pores in porous electrode materials is important for developing high-performance bioanodes.

\subsubsection{Bilirubin Oxidase}

Bilirubin oxidase (BOD) from Myrothecium verrucaria, a member of the multicopper oxidase family, reduces $\mathrm{O}_{2}$ to water in a DET-type bioelectrocatalysis [16]. As a result of its relatively high activity and relatively positive reduction potential for a four-electron dioxygen $\left(\mathrm{O}_{2}\right)$ reduction, $\mathrm{BOD}$ is an attractive catalyst for biocathodes in biofuel cells [9]. BOD contains four copper $(\mathrm{Cu})$ atoms classified into a Type 1 (T1) $\mathrm{Cu}$ site and a Type 2-3 (T2/3) Cu cluster. $\mathrm{O}_{2}$ is reduced at the T2/3 Cu cluster. According to the redox titration and site-specific mutation of BOD [16,34], an electrode-active redox center was assigned to the $\mathrm{T} 1 \mathrm{Cu}$ site. Therefore, an orientation in which the $\mathrm{T} 1 \mathrm{Cu}$ site faces the electrode (Figure 6A) is suitable for the DET-type bioelectrocatalysis compared with the opposite orientation in which the T2/3 Cu cluster faces the electrode (Figure 6B). It is well known that the orientation of adsorbed BOD (from Myrothecium verrucaria) was controlled by the surface modification of electrodes with negatively charged aromatic compounds $[19,35,36]$. Although the DET-type bioelectrocatalytic activity of BOD at planar glassy carbon electrodes is low, the activity was drastically enhanced at porous electrodes $[9,37]$.
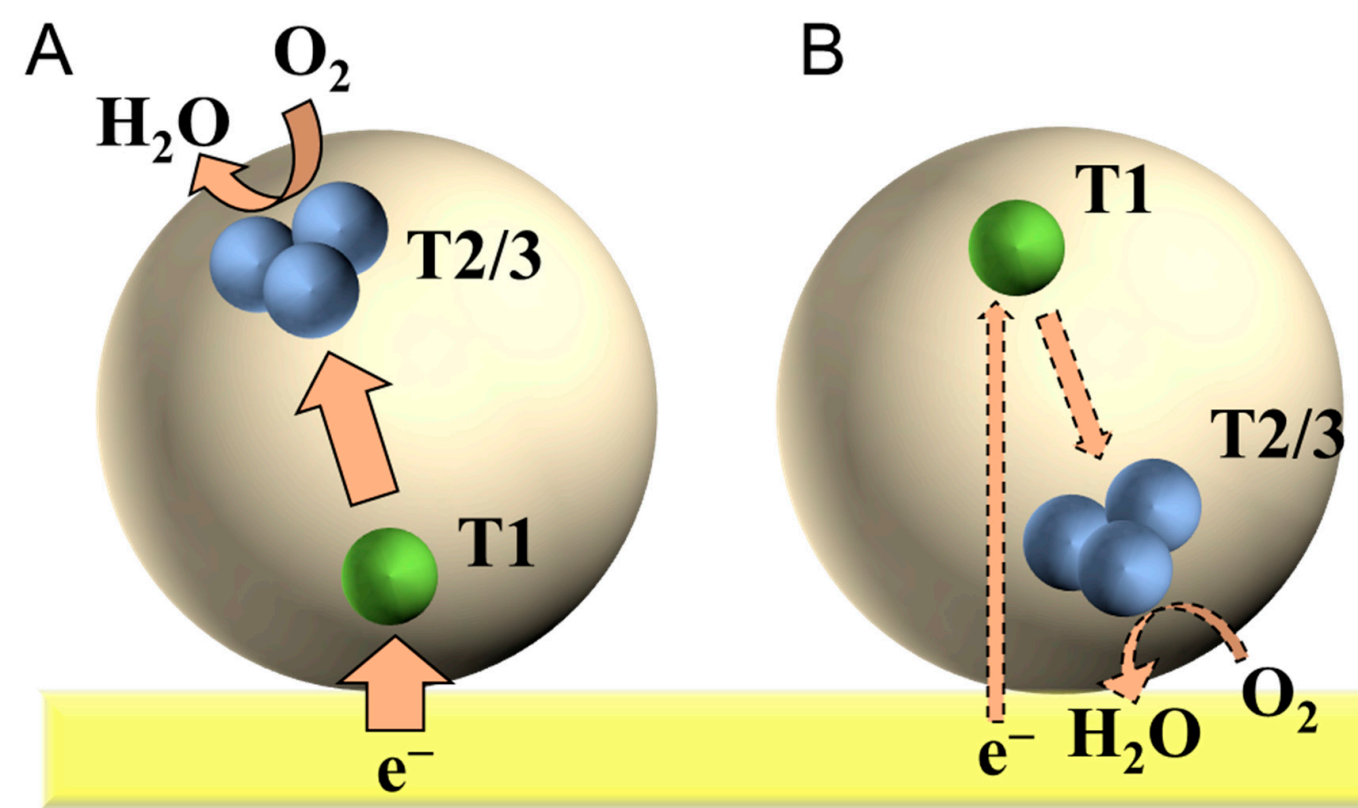

Figure 6. Schematic illustrations for the adsorbed bilirubin oxidas (BOD) at flat electrode in (A) effective and (B) invalid orientations for the DET-type bioelectrocatalysis. 
As a result of the limited solubility of $\mathrm{O}_{2}$ in aqueous solutions and a very high DET-type activity of $\mathrm{BOD}$, the catalytic reduction current density of $\mathrm{O}_{2}$ easily reaches the mass-transfer limited value. In such cases, analysis of steady-state catalytic waves obtained at rotating disk electrodes becomes very useful to get information of the orientation of BOD at porous electrodes. MgO-templated carbon electrodes with systematically controlled size pores (10 to $200 \mathrm{~nm}$ ) were investigated as scaffolds for BOD by rotating disk voltammetry [36]. The steady-state $\mathrm{O}_{2}$ reduction currents of the DET-type bioelectrocatalysis of BOD depended on the pore size and the rotating speed. The adsorbed amount of the enzyme per unit weight of the carbon material increased with an increase in the pore size. Moreover, the adsorbed amounts depended on the incubation time for the adsorption of BOD. When the pore size was small, the adsorption quickly reached saturation. The result shows that the penetration of the enzyme into the porous structures on the electrode surface is an important factor to control the adsorption amount of the enzyme on mesoporous electrode surfaces. The recorded voltammograms showed residual slope regions. The residual slopes at the voltammograms recorded at the MgO-templated carbon materials depended on the size of the porous structures; the contribution of the residual slope region on the voltammogram became large at electrodes with large pore sizes $(>100 \mathrm{~nm})$. The situation is similar to that observed at planar electrodes. On the other hand, when the pore sizes were small (10 and $20 \mathrm{~nm}$ ), the shape of the steady-state catalytic wave showed a typical sigmoidal shape. This is a typical curvature effect. The small pore seems to be effective to increase the probability of the orientations suitable for the DET-type bioelectrocatalysis. The stability of the adsorbed BOD was also affected by the pore size. A comparison of catalytic waves at electrodes with $40 \mathrm{~nm}$ and with $150 \mathrm{~nm}$ pores revealed that the $40 \mathrm{~nm} \mathrm{MgO}$-templated carbon was a more stable scaffold for the BOD adsorption [38].

\subsubsection{Hydrogenase}

Hydrogenase $\left(\mathrm{H}_{2}\right.$ ase $)$ catalyzes a reversible reaction between hydrogen $\left(\mathrm{H}_{2}\right)$ and proton $\left(\mathrm{H}^{+}\right)$. $\mathrm{H}_{2}$ ase is classified into three types ([Fe], [FeFe], and [NiFe]) on the basis of the metal component in its redox center. [NiFe] $\mathrm{H}_{2}$ ase is an attractive catalyst for biocathodes of $\mathrm{H}_{2} / \mathrm{O}_{2}$ biofuel cells thanks to its $\mathrm{O}_{2}$ tolerance [5,39]. A standard [NiFe] $\mathrm{H}_{2}$ ase from Desulfovibrio vulgaris Miyazaki $\mathrm{F}$ is constructed with large and small subunits. The large subunit contains an [NiFe] cluster, while the small subunit contains three FeS clusters which are called proximal, medial, and distal (Figure 7). The distal FeS cluster is considered to be the electrode-active redox center [40].

A

B
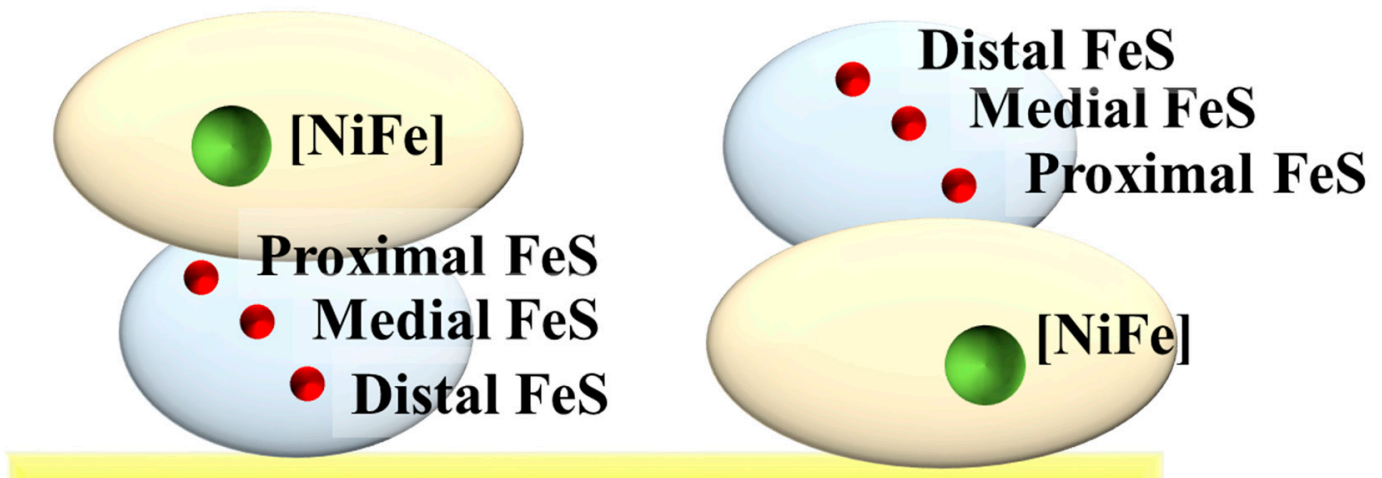

Figure 7. Schematic illustrations for the adsorbed $\mathrm{H}_{2}$ ase on a flat electrode in (A) effective and (B) invalid orientations for the DET-type bioelectrocatalysis.

The DET-type bioelectrocatalysis of $\mathrm{H}_{2}$ ase from Aquifex aeolicus was also investigated at MgO-templated carbon electrodes [41]. In this work, the bioelectrocatalytic behaviors at the electrodes 
of two pore sizes ( $35 \mathrm{~nm}$ and $150 \mathrm{~nm}$ ) were compared with each other; here, the size of the $\mathrm{H}_{2}$ ase in solution was determined to be $18 \mathrm{~nm}$ by dynamic light scattering. The results showed that the pore size affected the orientation and the amounts of the adsorbed enzymes on the electrode surface. The initial rising part in the steady-state catalytic wave at the electrode with the small pores was sharper than that with the large pores, indicating that the curvature effect was more evident on the electrode with the small pores. On the other hand, the amount of the adsorbed enzyme at the electrode with the large pores was demonstrably larger than that with the small pores. Analysis of the adsorption kinetics indicated that the large pores were convenient for the enzyme to penetrate deeply into the porous structures. For the enzyme, it seemed to be difficult to penetrate into the small pores, whose size is approximately double that of the enzyme size. It seems to be important to give it time to adsorb increased amounts of enzymes on porous electrodes that have a rather small radius.

In the case of the $\mathrm{H}_{2}$ ase also, the adsorption on the porous carbon electrodes stabilized the enzyme [40-42]. In addition, the stabilization effect was more evident at the electrode with the small pores than at that with the large pores. The restricted movement of the enzyme in mesoporous structures with a size close to the enzyme size seems to stabilize the enzyme.

\subsubsection{Histamine Dehydrogenase}

Histamine dehydrogenase from Nocardioides simplex $(\mathrm{HmDH})$ is one of the soluble iron-sulfur flavoproteins with a molecular mass of $152 \mathrm{kDa}$, and it contains flavin mononucleotide (FMN), a [4Fe-4S] cluster, and adenine diphosphate (ADP) as cofactors [43,44]. $\mathrm{HmDH}$ is capable of catalytically transferring electrons from histamine to electrodes. The electrode-active site in $\mathrm{HmDH}$ seems to be the [4Fe-4S] cluster. Porous electrodes fabricated from three carbon materials were investigated as scaffolds for the DET-type bioelectrocatalysis of HmDH [45]: Ketjen Black with a diameter of $40 \mathrm{~nm}$, carbon aerogel with a pore size of $10 \mathrm{~nm}$, and a carbon microsphere with a diameter of $100 \mathrm{~nm}$. Among the carbon materials, the DET-type bioelectrocatalysis of $\mathrm{HmDH}$ was detected only at the Ketjen Black-based porous electrode. The size of the carbon aerogel mesopore seems to be too small for $\mathrm{HmDH}$ to penetrate into the pore, while the size of the carbon microsphere macropore seems to be too large for $\mathrm{HmDH}$ to enjoy the curvature effect.

\subsection{Nanoporous Metals and Aggregated Metal Nanoparticles}

The synthesis of monodispersed nanoparticles has developed for a long time [46,47]. The aggregation of monodispersed spherical nanoparticles will provide ordered mesopores (gaps) among the surrounding nanoparticles, as shown in Figure 8A. The maximum diameter of the inscribed spheres that can fit in the mesopore is about approximately 0.3 the size of the diameter of the nanoparticles (Figure 8B). Such a modification of the electrode surface with monodispersed nanoparticles is regarded as an easy method to provide controlled mesoporous structures. By considering the curvature effect, the most effective mesopores among the surrounding nanoparticles for the adsorption of enzymes may be provided by nanoparticles with radii that are three to four times larger than the size of a target enzyme; multipoint contact between an enzyme in the mesopores and the surrounding nanoparticles enjoy the curvatures effect for DET-type bioelectrocatalysis.

On the other hand, the mesopores among the surrounding nanoparticles are not spheres. This structure seems to be very important for the mass transfer of substrates and products.

As a result, such porous structures constructed by large nanoparticles are generally more effective for DET-type bioelectrocatalysis than the planar structure [48]. Although the improvement of DET-type bioelectrocatalysis by combinations of porous carbon electrodes and metal nanoparticles has been widely investigated [49,50], some examples of DET-type bioelectrocatalysis on metal-based nanoporous structures are described here. 
A

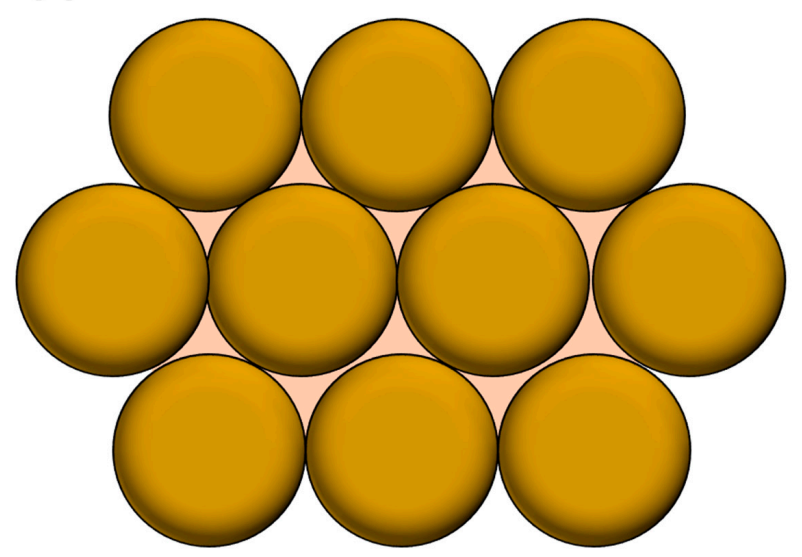

B

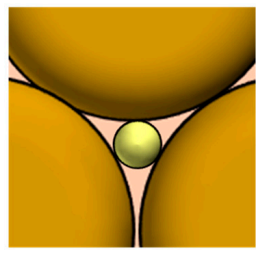

Figure 8. (A) A simple model of the aggregated nanoparticles. (B) Schematic view of an inscribed sphere in a pore between the closed packed spheres.

\subsubsection{Hydrogenase}

Monsalve et al. demonstrated that layered gold nanoparticles with a diameter of 25 nm were effective scaffolds for the DET-type bioelectrocatalytic oxidation of $\mathrm{H}_{2}$ by $\mathrm{H}_{2}$ ase from Aquifex aeolicus [51]. When the adsorbed amount of the nanoparticles was small-that is, when the electrochemically active surface area was less than 10 times that of the projected area (the surface area of the planar electrode), the current density (per projected surface area) of the DET-type bioelectrocatalysis of the $\mathrm{H}_{2}$ ase remained very small and unchanged in spite of an increase in the electrochemically active surface area. However, clear catalytic waves were observed when the electrochemically active surface area became more than 10 times that of the projected one, and the current density (per projected surface area) increased with the electrochemically active surface area up to at least 25 times that of the projected one. The results show that coarse aggregations constructed with insufficiently packed nanoparticles are not suitable scaffolds for the DET-type reaction of the adsorbed enzyme. In contrast, the mesoporous spaces constructed among densely packed nanoparticles are suitable scaffolds for the DET-type bioelectrocatalysis. In addition, the aggregates constructed with gold nanoparticles with a diameter of $25 \mathrm{~nm}$ provided more suitable scaffolds for the DET-type reaction of the $\mathrm{H}_{2}$ ase than those with a diameter of $35 \mathrm{~nm}$; the diameters of the mesoporous spaces provided by the gold nanoparticles with a diameter of $35 \mathrm{~nm}$ seem to be too large for the $\mathrm{H}_{2}$ ase to enjoy the curvature effect. All these results demonstrate that the size of mesoporous space constructed in gaps in nanoparticle aggregates is a very important factor for the DET-type bioelectrocatalytic activity of $\mathrm{H}_{2}$ ases.

\subsubsection{Bilirubin Oxidase}

The DET-type bioelectrocatalysis of BOD at gold nanoparticle submonolayer-modified electrodes was systematically investigated by Pankratov et al. [52]. The sizes of the nanoparticles investigated were 20, 40,60, and $80 \mathrm{~nm}$. The kinetic analysis based on the real surface area showed that the electroenzymatic kinetics were almost independent of the size of the nanoparticles. This result suggests that only the densely aggregated nanoparticles provide scaffolds suitable for the DET-type bioelectrocatalysis of BOD.

On the other hand, some methodologies to fabricate microporous gold electrodes have been developed. The anodization of gold in a buffer solution containing glucose as a reductant is one of the fabrication methods of microporous gold materials [21]. The microscopic observation of the fabricated microporous gold electrode fabricated in a glucose solution showed that microporous structures were constructed from the gold nanoparticles [21,48]. The constructed microporous gold electrodes work as effective scaffolds for the DET-type bioelectrocatalysis of BOD. On the other hand, electrodes with low densities of microporous structures were not effective for the DET reaction of BOD. All these results 
show the importance of three-dimensional mesoporous structure constructed with nanoparticles but not nanoparticles themselves.

Nanoporous gold (NPG) electrodes constructed by dealloying silver/gold alloy in nitric acid solutions were investigated as scaffolds for the DET-type bioelectrocatalysis of BOD [53]. The average pore sizes of the NPG materials were controlled by dealloying conditions to be 9, 15, 24, 41, 45, and $61 \mathrm{~nm}$. The residual slope on the voltammogram showed that the porous gold materials with an average pore size of $9 \mathrm{~nm}$ were the most suitable scaffolds for the DET-type bioelectrocatalysis of BOD. Based on the crystal structure of BOD [54,55], the shape of BOD can be considered as a sphere with a diameter of $5 \mathrm{~nm}$. Comparison of the size between the most effective pore and the enzyme supports the curvature effect of the mesoporous structure on the DET-type bioelectrocatalysis.

\subsubsection{Fructose Dehydrogenase}

NPG electrodes constructed by dealloying a silver/gold alloy were investigated as scaffolds for the DET-type bioelectrocatalysis of FDH [56]. The average pore sizes of the NPG materials examined were 9, 18, 42, and $62 \mathrm{~nm}$. The catalytic current density (per projected area) increased with an increase in the pore size from 9 to $42 \mathrm{~nm}$, while the current density decreased on the electrode with an average pore size of $62 \mathrm{~nm}$. The highest current densities were obtained with NPG electrodes with an average pore size of $42 \mathrm{~nm}$. In the experiments, the shape of the steady-state catalytic waves was almost independent of the average pore size. Therefore, the difference in the current density seems to be ascribed predominantly to the difference in the adsorbed amount of FDH.

\section{Protein Engineering Methods for the Improvement of DET-Type Bioelectrocatalytic Performance}

For the practical application of bioelectrocatalysis to bioelectrochemical devices such as biosensors, bioreactors, biofuel cells, and biosupercapacitors, enzyme-functionalized electrodes are required to satisfy the following two improvements: one is an increase in a catalytic current density and the other is a decrease in overpotential. The former may be solved by getting the catalytic constant of enzymes higher or increasing the amount of enzymes adsorbed on the electrode surface. The latter may be realized by shifting the formal potential of the electrode-active redox site of enzymes negatively for oxidative reactions of substrates (and positively for reductive reactions). Some enzymes are tuned by protein engineering methods to improve the DET-type bioelectrocatalytic properties.

It has been reported that some FDH variants show better DET-type bioelectrocatalytic performance than the wild-type (or recombinant native) FDH [28]. Considering the comparison of the formal potentials of hemes $c$ and the onset potential of the steady-state catalytic wave of the DET-type bioelectrocatalysis, it was suggested that electrons were transferred from $\mathrm{D}$-fructose to an electrode via $\mathrm{FAD}$, heme $3 c$, and $2 c$ in this order, and heme $1 c$ seemed to be uninvolved in the intramolecular electron transfer in the DET-type reaction, as shown in Figure 9 [32].

These suggestions were proved by investigating FDH variants (M450Q and $\left.\Delta 1 c \_F D H\right)$. In the M450Q variant, M450, which is the sixth axial ligand of heme $2 c$, was replaced with glutamine in order to shift the formal potential of heme $2 c$ in the negative direction, and the half-wave potential of the steady-state catalytic wave of the M450Q variant shifted negatively as expected [57]. The $\Delta 1 c \_F D H$ variant lacking the heme $1 c$ moiety showed an increase in the limiting catalytic current density, which was probably thanks to the downsizing of the enzyme [58]. In addition, a double variant (M450Q $\left.\Delta 1 c \_F D H\right)$ showed improved characteristics observed for both M450Q and $\Delta 1 c_{-}$FDH [59].

On the other hand, a $\Delta 1 c 2 c \_F D H$ variant, which lacked both the heme $1 c$ and $2 c$ moieties, showed a DET-type bioelectrocatalytic wave that was very similar to that of M450Q $\Delta 1 c_{-}$FDH [60]: an increase in the limiting catalytic current density caused by the downsizing of the enzyme and a decrease in the overpotential thanks to the direct heterogeneous electron transfer from heme $3 c$ with the most negative formal potential to an electrode. The DET-type bioelectrocatalytic waves of these FDH variants are shown in Figure 10. 


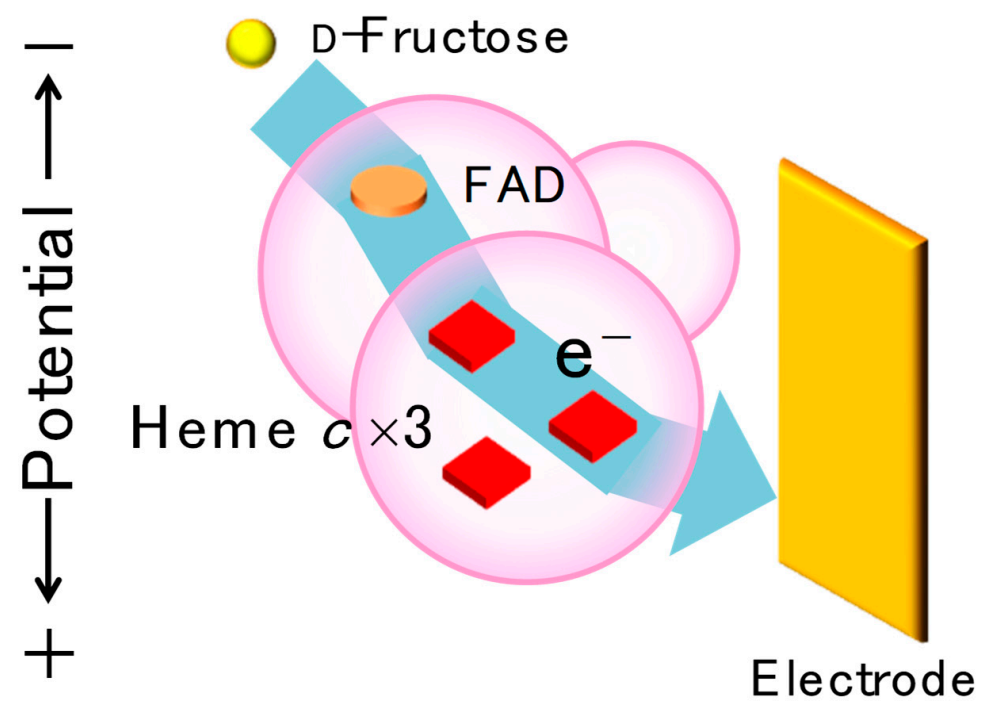

Figure 9. Schematic view of proposed electron transfer pathway from D-fructose to an electrode in a DET-type reaction of d-fructose dehydrogenase (FDH). The electrons are transferred from substrate-reduced FAD to heme $3 c$, heme $2 c$, and an electrode without going to heme $1 c$. Reprinted from [28], Copyright (2019), with permission from Elsevier.
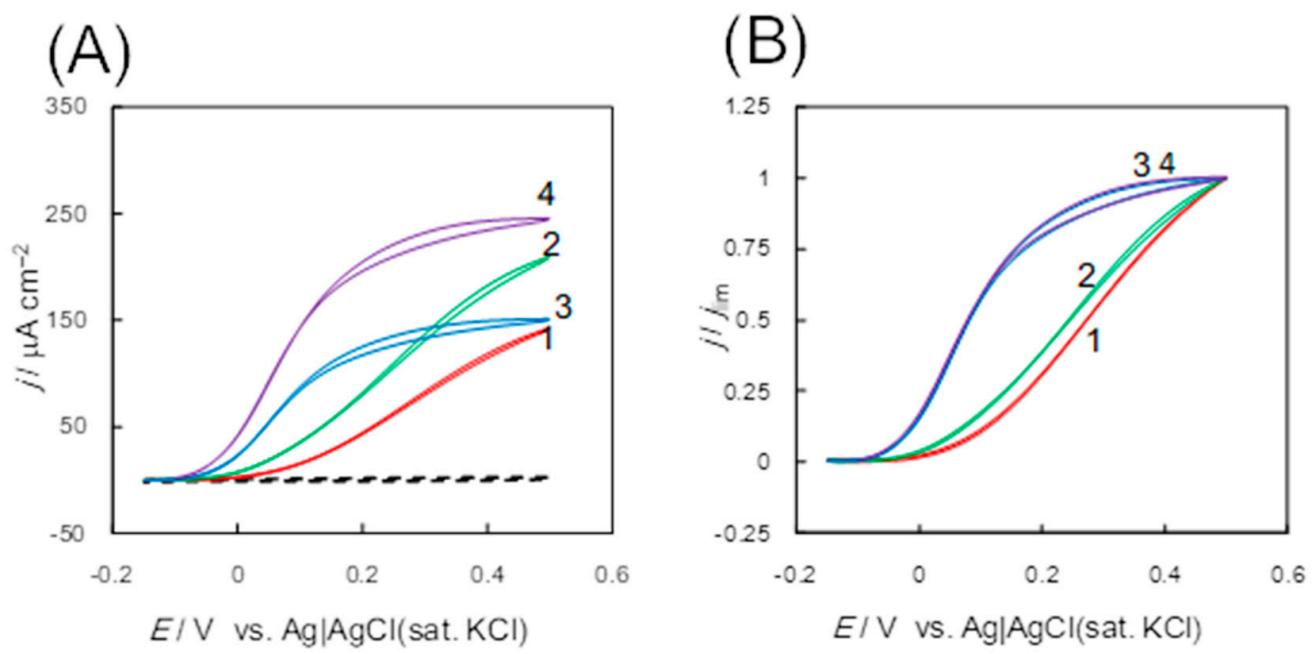

Figure 10. Original (A) and normalized (B) cyclic voltammograms (CVs) of D-fructose oxidation at $\mathrm{Au}$ electrodes on the surface that had been adsorbed the $\mathrm{D}$-fructose dehydrogenase variants; the recombinant FDH (1, red), $\Delta 1$ __FDH (2, green), $\Delta 1 c 2 c_{-}$FDH (3, blue), and M450Q $\Delta 1$ c_FDH (4, purple) in a Mcllvaine buffer ( $\mathrm{pH} 4.5$ ) containing $0.1 \mathrm{M}$ D-fructose under anaerobic conditions at a scan rate $(v)$ of $10 \mathrm{mV} \mathrm{s}^{-1}$. The dashed line in panel (A) represents a background voltammogram obtained using a bare Au electrode. Reprinted from [28], Copyright (2019), with permission from Elsevier.

As well as FDH, FAD-dependent glucose dehydrogenase (FAD-GDH) from Burkholderia cepacia belongs to the bacterial FAD-dependent dehydrogenase family $[61,62]$, and the DET-type bioelectrocatalysis of FAD-GDH was investigated [63-66]. FAD-GDH is a heterotrimer consisting of three subunits: $\alpha$ subunit $(60 \mathrm{kDa})$ harboring a FAD catalytic center and an iron-sulfur (FeS) cluster (3Fe-4S), $\beta$ subunit ( $43 \mathrm{kDa}$ ) containing three hemes $c$ (heme $1 c, 2 c$, and $3 c$ from the $\mathrm{N}$-terminus), and $\gamma$ subunit $(18 \mathrm{kDa})$ working as a chaperon $[67,68]$. Based on the mutagenesis studies of FAD-GDH, the electrons produced by glucose oxidation were proposed to pass to an electrode through FAD, $3 \mathrm{Fe}-4 \mathrm{~S}$, heme $3 c$, and $2 c$ in this order [69]. Based on the proposal, an FAD-GDH variant $(\operatorname{tr} \beta)$, of which heme $1 c$ and $3 c$ moieties are truncated, was designed, and $\operatorname{tr} \beta$ showed improved water solubility and 
DET-type bioelectrocatalytic activity with lower overpotential than that of the wild-type FAD-GDH [62]. These results can be interpreted an in the case of FDH. In addition, FAD-GDH variants (Ala472Phe and Asn475Asp) improved the substrate specificity toward glucose [70].

On the other hand, fusion protein engineering is also a general method for achieving DET-type bioelectrocatalysis. A model enzyme was cellobiose dehydrogenase $(\mathrm{CDH})$, which is a DET-type bioelectrocatalyst that consists of two domains: a larger catalytic dehydrogenase domain $\left(\mathrm{DH}_{\mathrm{CDH}}\right)$ includes a non-covalently bound FAD and oxidizes substrates, while a smaller cytochrome domain $\left(\mathrm{CYT}_{\mathrm{CDH}}\right)$ contains heme $b$ and communicates with electrodes [71]. The $\mathrm{DH}_{\mathrm{CDH}}$ and $\mathrm{CYT}_{\mathrm{CDH}}$ are connected through a flexible polypeptide linker, and the intramolecular electron transfer between two domains occurs easily [71]. As a mimic of $\mathrm{CDH}$, several redox enzymes were fused with the cytochrome domains of other enzymes through a linker and DET-type reactions of them were realized or improved: e.g., pyrroloquinoline quinone (PQQ)-dependent glucose dehydrogenase (PQQ-GDH) from Acinetobacter calcoaceticus [72], FAD-GDH from Burkholderia cepacia [73] and Aspergillus flavus [74], and flavodoxin from Desulfovibrio vulgaris [75]. The cytochrome domain worked as a "built-in mediator" and improved the heterogeneous electron transfer kinetics between the enzymes and electrodes, as shown in Figure 11.

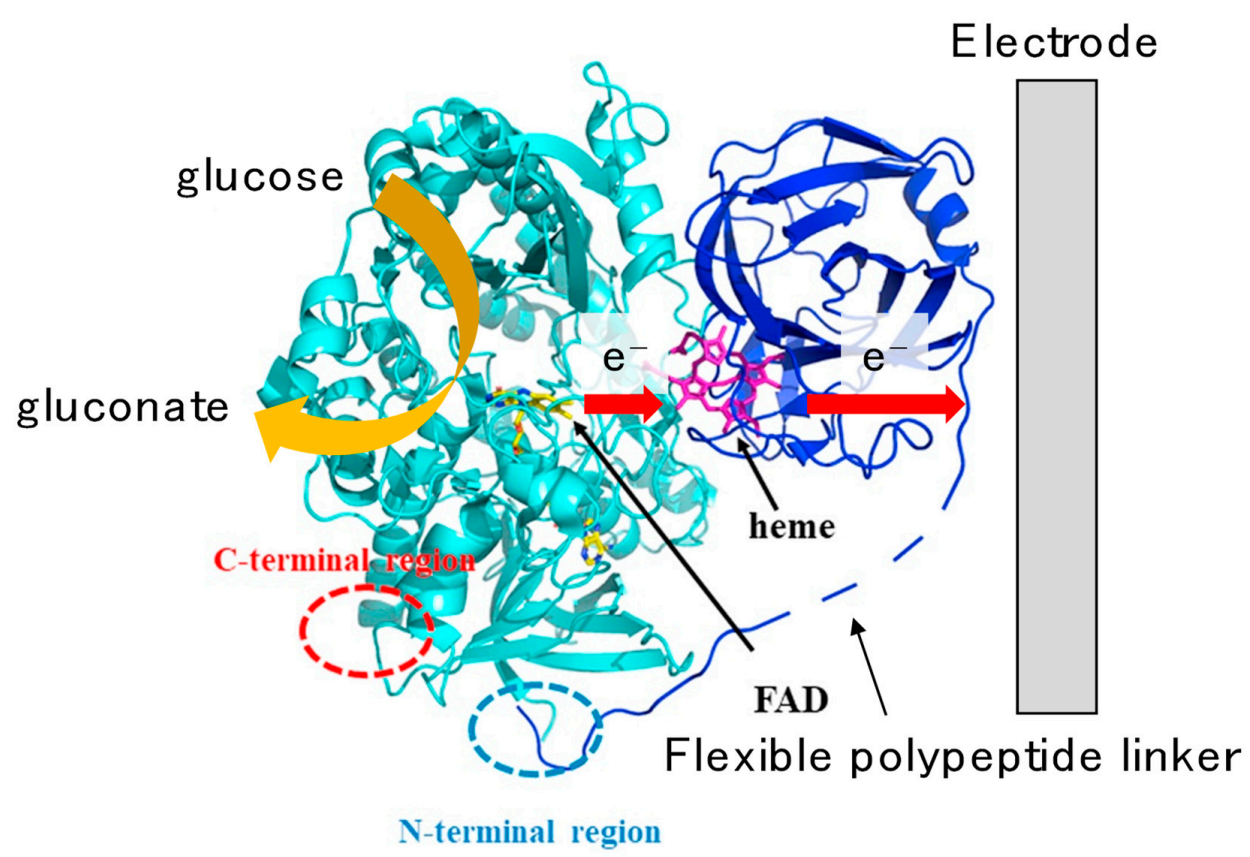

Figure 11. Model structure and the electron transfer pathway from glucose to an electrode in a direct-electron-transfer-type reaction of a fusion protein of flavin adenine dinucleotide-dependent glucose dehydrogenase (FAD-GDH) from Aspergillus flavus and $\mathrm{CYT}_{\mathrm{CDH}}$. The electrons are transferred from FAD to an electrode via heme $b$. Reproduced from Ref. [74], Copyright (2019), with permission from Elsevier, and modified in part.

In addition, the site-directed mutagenesis of enzymes is incorporated to improve the DET-type bioelectrocatalytic performance. In order to increase the stability of enzymes and bioelectrochemical devices, disulfide bonds are often introduced. A PQQ-GDH variant in which one of the amino acids was replaced with cysteine showed increased stability compared with the wild-type thanks to its dimeric structure constructed by enhanced intermolecular disulfide bonds [76]. The importance of the dimeric or oligomeric structure for the enzyme stability was supported by the following works: (1) other PQQ-GDH variants in which hydrophobic amino acids were introduced seemed to become a dimer by enhanced hydrophobic interaction and also showed high stability [77], while (2) chemically oligomerized FAD-dependent glucose oxidase (FAD-GOD) exhibited higher thermal stability than the 
native one [78]. The limitation of the enzyme mobility seems to improve the stability, as observed in the case that enzymes were embedded (or adsorbed) in mesoporous structures with a size close to that of the enzymes.

Cysteine-introduced variants are also effective for forming covalent bonds and for promoting the attractive interaction between the enzymes and electrodes (or conductive materials). It was reported that FAD-GOD variants in which the surface cysteine mutation was introduced formed thioether bonds with maleimido-modified gold nanoparticles and performed a DET-type reaction [79]. In addition, Gorton et al. investigated the effects of cysteine mutations on the DET-type bioelectrocatalysis of recombinant horseradish peroxidase (rHRP) on gold electrodes and claimed that the surface cysteine controlled the orientation of the enzymes adsorbed on the electrode and that several variants improved the DET-type performance [80]. On the other hand, enzymes expressed in E. coli lack glycosylation shells, and the downsizing of the enzymes may shorten the distance between the electrode-active site and electrodes, which may lead to an improvement of DET-type bioelectrocatalysis [81].

On the other hand, the directed evolution of enzymes is also useful for DET-type bioelectrocatalysis [81-83]. For example, laccase variants engineered by directed evolution showed a shift of the optimum $\mathrm{pH}$ from acidic to neutral conditions and also the chloride tolerance, which seemed to be favorable for practical use under physiological conditions [84].

\section{Interconversion of Redox Couples by Bidirectional DET-Type Bioelectrocatalysis}

Some redox enzymes catalyze two-way reactions (both the oxidation and reduction) of substrate redox couples. One of the requirements for the two-way reaction is that the formal potentials of the substrate redox couple and the cofactor in enzymes are close to each other in order to minimize the kinetic barrier of uphill intramolecular electron transfer of one of the two-way reactions in the enzymes. Here, the rate constant of the electron transfer reaction $(k)$ is expressed by the following Marcus cross-relation [85]:

$$
k \cong \sqrt{k_{\mathrm{DD}} k_{\mathrm{AA}} \exp \left(-\frac{\Delta_{\mathrm{r}} G^{\circ}}{R T}\right)}
$$

where $k_{\mathrm{DD}}$ and $k_{\mathrm{AA}}$ are the rate constants of the self-electron-exchange reactions at the redox site in the enzyme as electron-donating and accepting sites, respectively. $\Delta_{\mathrm{r}} G^{\circ}$ is the standard Gibbs energy of the electron transfer reaction and is given by:

$$
\Delta_{\mathrm{r}} G^{\circ}=-n F\left(E_{\mathrm{AA}}^{\circ \prime}-E_{\mathrm{DD}}^{\circ \prime}\right)
$$

where $E^{\circ \prime} \mathrm{AA}$ and $E^{\circ \prime} \mathrm{DD}$ are the formal potential of the electron-accepting and donating sites, respectively. In order to decrease $\Delta_{\mathrm{r}} G^{\circ}$ in uphill processes $\left(\Delta_{\mathrm{r}} G^{\circ}>0, E^{\circ \prime} \mathrm{AA}<E^{\circ \prime} \mathrm{DD}\right), E^{\circ \prime}$ AA should be close to $E^{\circ \prime} \mathrm{DD}$. This is the reason for the requirement mentioned above. The other requirement for the fast electron transfer of uphill reactions is that $k_{\mathrm{DD}}$ and $k_{\mathrm{AA}}$ should be very large, as expected from Equation (11). Since the rate constant of a self-exchange reaction $\left(k_{\text {self }}\right)$ is related to the reorganization energy $(\lambda)$;

$$
R T \ln \frac{k_{\text {self }}}{Z}=-\Delta^{\ddagger} G_{\text {self }}^{\circ}=-\frac{\lambda}{4},
$$

a low value of $\lambda$ is essential for uphill electron transfer. Here, $Z$ is a coefficient of the absolute kinetics and $\Delta^{\ddagger} G^{\circ}$ self is the standard Gibbs energy of activation. A low $\lambda$ value is realized in a minimum change in geometry during the redox reaction. The peptide matrix frequently plays an important role in minimizing the geometric change. Therefore, an uphill electron transfer may be observed in intramolecular electron transfer in redox proteins in some instances.

Bidirectional bioelectrocatalysis is useful to construct effective energy conversion systems. Examples of the interconversion system reported for $\mathrm{H}_{2}$ ase, formate dehydrogenase (FoDH), and ferredoxin-nicotinamide adenine dinucleotide phosphate $\left(\mathrm{NADP}^{+}\right)$reductase (FNR) are shown in the following section. 


\subsection{Hydrogenase}

It is well known that $\mathrm{H}_{2}$ ase catalyzes $\mathrm{H}_{2}$ oxidation and $\mathrm{H}^{+}$reduction, and it communicates with an electrode directly at the distal FeS cluster [5,39]. The formal potential of the $2 \mathrm{H}^{+} / \mathrm{H}_{2}$ couple is $-0.614 \mathrm{~V}$ versus $\mathrm{Ag}|\mathrm{AgCl}|$ sat. $\mathrm{KCl}$ at $\mathrm{pH}$, which is close to that of the distal $\mathrm{FeS}$ cluster $(-0.54 \mathrm{~V}$ for $\mathrm{H}_{2}$ ase from Desulfovibrio fructosovorans [86]). The closeness of the formal potentials is responsible for the reversibility of the $\mathrm{H}_{2}$ ase reaction. Moreover, nicotine adenine dinucleotide $\left(\mathrm{NAD}^{+}\right.$)-reducing [NiFe]-hydrogenase, which has a diaphorase subunit, shows bidirectional DET-type bioelectrocatalysis interconverting not only $2 \mathrm{H}^{+} / \mathrm{H}_{2}$ but also $\mathrm{NAD}^{+} / \mathrm{NADH}[87,88]$.

\subsection{Formate Dehydrogenase}

Tungsten or molybdenum-containing FoDHs from Methylobacterium extorquens AM1, Syntrophobacter fumaroxidans, and Escherichia coli were reported to show DET-type bioelectrocatalytic interconversion between carbon dioxide $\left(\mathrm{CO}_{2}\right)$ and formate $\left(\mathrm{HCOO}^{-}\right)$[89-91]. FoDHs have tungstopterin or molybdopterin as a catalytic center and FeS clusters as the electrode-active redox site [89-91] with a formal potential of $-0.59 \mathrm{~V}$ for Methylobacterium extorquens AM1 [89], which is close to that of the $\mathrm{CO}_{2} / \mathrm{HCOO}^{-}$couple (-0.63 V at pH 7.0 [92]). In addition, FoDH from Methylobacterium extorquens AM1 (FoDH1), which has a non-covalently bound flavin adenine dinucleotide (FMN), catalyzes a bidirectional interconversion between $\mathrm{NAD}^{+}$and $\mathrm{NADH}$ (the formal potential of the $\mathrm{NAD}^{+} / \mathrm{NADH}$ couple being $-0.52 \mathrm{~V}$ at $\mathrm{pH} 7.0$ [89]), and a four-way DET-type bioelectrocatalysis $\left(\mathrm{CO}_{2} / \mathrm{HCOO}^{-}\right.$and $\left.\mathrm{NAD}^{+} / \mathrm{NADH}\right)$ was shown at mesoporous carbon electrodes constructed with 4-mercaptopyridine-modified gold nanoparticles; the modified gold particles controlled the orientation of FoDH and enhanced the heterogeneous electron transfer kinetics between the enzyme and the electrode [89]. Examples of DET-type bioelectrocatalytic waves in a four-way reaction of FoDH1 are shown in Figure 12. Besides that, an external powerless bioelectrochemical interconversion between $\mathrm{HCOO}^{-}$and $\mathrm{H}_{2}$ was accomplished by coupling two bioelectrocatalytic reactions of $\mathrm{H}_{2}$ ase and FoDH (note that FoDH plays as a MET-type bioelectrocatalyst) [93].
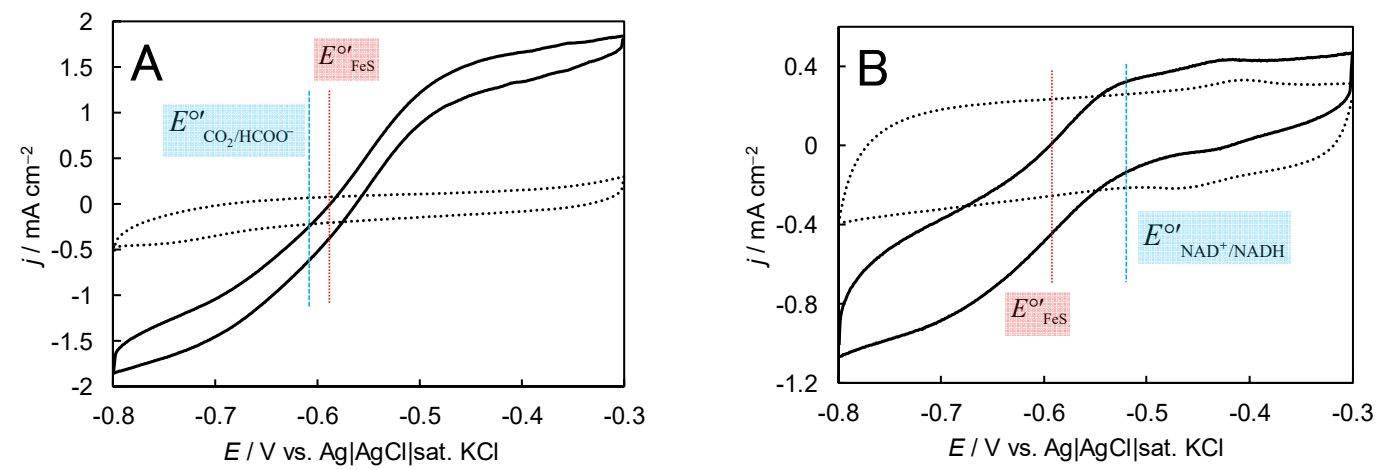

Figure 12. (A) Cyclic voltammograms $(\mathrm{CVs})$ for $\mathrm{HCOO}^{-}$oxidation and $\mathrm{CO}_{2}$ reduction at FoDH-modified mesoporous carbon electrodes constructed with 4-mercaptopyridine-modified gold nanoparticles in 1.0 M phosphate buffer ( $\mathrm{pH}$ 6.6) containing $10 \mathrm{mM}$ HCOONa under $\mathrm{CO}_{2}$ gas-saturated and quiescent conditions at $25{ }^{\circ} \mathrm{C}$ and $v=10 \mathrm{mV} \mathrm{s}^{-1}$. The dotted lines represent $\mathrm{CVs}$ in the absence of the substrate. $E^{\circ \prime} \mathrm{CO}_{2} / \mathrm{HCOO}^{-}$(the blue line) and $E^{\circ \prime} \mathrm{FeS}$ (the red line) are the formal potentials of the $\mathrm{CO}_{2} / \mathrm{HCOO}^{-}$couple and the electrode-active FeS cluster in $\mathrm{FoDH}$, respectively. (B) CVs for NADH oxidation and $\mathrm{NAD}^{+}$reduction at FoDH1-modified mesoporous carbon electrodes constructed with 4-mercaptopyridine-modified gold nanoparticles in $1.0 \mathrm{M}$ phosphate buffer ( $\mathrm{pH}$ 7.0) containing $50 \mathrm{mM}$ $\mathrm{NAD}^{+}$and NADH under argon-saturated and quiescent conditions at $25{ }^{\circ} \mathrm{C}$ and $v=10 \mathrm{mV} \mathrm{s}^{-1}$. The dotted line represents the $\mathrm{CV}$ in the absence of substrate. $E^{\circ \prime} \mathrm{NAD}^{+} / \mathrm{NADH}$ (the blue line) and $E^{\circ \prime} \mathrm{FeS}$ (the red line) are the formal potentials of the $\mathrm{NAD}^{+} / \mathrm{NADH}$ couple and the electrode-active FeS cluster in FoDH, respectively. Reprinted from [89], Copyright (2017), with permission from Elsevier, and modified in part. 


\subsection{Ferredoxin-NADP+ Reductase}

FNR from Chlamidomonas reinhardtii is a monomeric flavoenzyme with a molecular mass of $45 \mathrm{kDa}$ and catalyzes the two-electron reduction of $\mathrm{NADP}^{+}$to NADPH at the end of the photosynthetic electron transport chain [94]. In spite of that, the enzyme has only a single redox cofactor (a non-covalently bound FAD), and unlike the enzymes described above, FNR performed a reversible DET-type reaction of the $\mathrm{NADP}^{+} / \mathrm{NADPH}$ redox couple, and the reaction was coupled with $\mathrm{NADP}^{+}$-dependent enzymes to construct bioreactors with minimum overpotentials [94,95].

\section{Conclusions}

Bioelectrocatalysis is rapidly evolving and will be employed to establish a broadly applicable technology. Increasing attention in this area is driven by remarkable progress in designing electrode surfaces for fast electron transfer kinetics between redox enzymes and electrodes and in the protein engineering of enzymes. We may make use of a variety of redox enzymes as electrocatalysts in practice, although we have to tackle a great challenge in increasing the lifetime of redox enzymes in the future. Further investigations for a deeper understanding of electroenzymatic reactions will be also required. All these efforts are valuable in establishing bioelectrochemistry on bioelectrocatalysis as a practical technique for different applications and also as a novel tool for redox enzyme research studies.

Funding: This research received no external funding.

Conflicts of Interest: The authors declare no conflict of interest.

\section{References}

1. Bartlett, P.N. Bioelectrochemistry: Fundamentals, Experimental Techniques and Applications; John Wiley \& Sons: Hoboken, NJ, USA, 2008.

2. Barton, S.C.; Gallaway, J.; Atanassov, P. Enzymatic biofuel cells for implantable and microscale devices. Chem. Rev. 2004, 104, 4867-4886. [CrossRef] [PubMed]

3. Léger, C.; Bertrand, P. Direct electrochemistry of redox enzymes as tool for mechanistic studies. Chem. Rev. 2008, 108, 2379-2438. [CrossRef] [PubMed]

4. Cracknell, J.A.; Vincent, K.A.; Armstrong, F.A. Enzymes as working or inspirational electrocatalysts for fuel cells and electrolysis. Chem. Rev. 2008, 108, 2439-2461. [CrossRef]

5. Armstrong, F.A.; Hirst, J. Reversibility and efficiency in electrocatalytic energy conversion and lessons from enzymes. Proc. Natl. Acad. Sci. USA 2011, 108, 14049-14054. [CrossRef] [PubMed]

6. Meredith, M.T.; Minteer, S.D. Biofuel cells; enhanced enzymatic bioelectrocatalysis. Annu. Rev. Anal. Chem. 2012, 5, 157-179. [CrossRef]

7. De Poulpiquet, A.; Ranava, D.; Monsalve, K.; Giudici-Orticoni, M.T.; Lojou, E. Biohydrogen for a new generation of $\mathrm{H}_{2} / \mathrm{O}_{2}$ biofuel cells: A sustainable energy perspective. ChemElectroChem 2014, 1, 1724-1750. [CrossRef]

8. Mazurenko, I.; de Poulpiquet, A.; Lojou, E. Recent developments in high surface area bioelectrodes for enzymatic fuel cells. Curr. Opin. Electrochem. 2017, 5, 74-84. [CrossRef]

9. Mano, N.; de Poulpiquet, A. $\mathrm{O}_{2}$ reduction in enzymatic biofuel cells. Chem. Rev. 2018, 118, 2392-2468. [CrossRef]

10. Milton, R.D.; Minteer, S.D. Enzymatic bioelectrosynthetic ammonia production: Recent electrochemistry of nitrogenase, nitrate reductase, and nitrite reductase. ChemPlusChem 2017, 82, 513-521. [CrossRef]

11. Fourmond, V.; Léger, C. Modelling the voltammetry of adsorbed enzymes and molecular catalysts. Curr. Opin. Electrochem. 2017, 1, 110-120. [CrossRef]

12. Willner, I.; Katz, E.; Willner, B. Electrical contact of redox enzyme layers associated with electrodes; routes to amperometric biosensors. Electroanalysis 1997, 9, 965-977. [CrossRef]

13. Bollella, P.; Gorton, L. Enzyme based amperometric biosensors. Curr. Opin. Electrochim. 2018, 10, 157-173.

14. Krieg, T.; Sydow, A.; Schröder, U.; Schrader, J.; Holtmann, D. Reactor concepts for bioelectrochemical syntheses and energy conversion. Trends Biotechnol. 2014, 32, 645-655. [CrossRef] [PubMed] 
15. Shleev, S.; González-Arribas, E.; Falk, M. Biosupercapacitors. Curr. Opin. Electrochem. 2017, 5, $226-233$. [CrossRef]

16. Tsujimura, S.; Nakagawa, T.; Kano, K.; Ikeda, T. Kinetic study of direct bioelectrocatalysis of dioxygen reduction with bilirubin oxidase at carbon electrodes. Electrochemistry 2004, 72, 437-439. [CrossRef]

17. Bard, A.J.; Faulkner, L.R. Electrochemical Methods Fundamentals and Applications, 2nd ed; John Wiley \& Sons: Hoboken, NJ, USA, 2001.

18. Léger, C.; Jones, A.K.; Albracht, S.P.J.; Armstrong, F.A. Effect of a dispersion of interfacial electron transfer rates on steady state catalytic electron transport in [NiFe]-hydrogenase and other enzymes. J. Phys. Chem. B 2002, 106, 13058-13063. [CrossRef]

19. Xia, H.-Q.; Kitazumi, Y.; Shirai, O.; Kano, K. Enhanced direct electron transfer-type bioelectrocatalysis of bilirubin oxidase on negatively charged aromatic compound-modified carbon electrode. J. Electroanal. Chem. 2016, 763, 104-109. [CrossRef]

20. Sugimoto, Y.; Takeuchi, R.; Kitazumi, Y.; Shirai, O.; Kano, K. Significance of mesoporous electrodes for noncatalytic faradaic process of randomly oriented redox proteins. J. Phys. Chem. C 2016, 120, 26270-26277. [CrossRef]

21. Sakai, K.; Xia, H.-Q.; Kitazumi, Y.; Shirai, O.; Kano, K. Assembly of direct-electron-transfer-type bioelectrodes with high performance. Electrochim. Acta 2018, 271, 305-311. [CrossRef]

22. Kitazumi, Y.; Shirai, O.; Kano, K. Significance of nanostructures of an electrode surface in direct electron transfer-type bioelectrocatalysis of redox enzymes. ACS Symposium Series 1342. In Novel Catalyst Materials for Bioelectrochemical Systems: Fundamentals and Applications; Lakhveer Singh, L., Mahapatra, D.M., Liu, H., Eds.; American Chemical Society: Washington, DC, USA, 2020.

23. Sakintuna, B.; Yürüm, Y. Templated porous carbons: A reviewarticle. Ind. Eng. Chem. Res. 2005, 44, 2893-2902. [CrossRef]

24. Lee, J.; Kim, J. Hyeon, Recent progress in the synthesis of porous carbon materials. Adv. Mater. 2006, 18, 2073-2094. [CrossRef]

25. Ma, T.-Y.; Liu, L.; Yuan, Z.-Y. Direct synthesis of ordered mesoporous carbons. Chem. Soc. Rev. 2013, 42, 3977-4003. [CrossRef]

26. Morishita, T.; Tsumura, T.; Toyoda, M.; Przepiórski, J.; Morawski, A.W.; Konno, H.; Inagaki, M. A review of the control of pore structure in MgO-templated nanoporous carbons. Carbon 2010, 48, 2690-2707. [CrossRef]

27. Inagaki, M.; Toyoda, M.; Soneda, Y.; Tsujimura, S.; Morishita, T. Templated mesoporous carbons: Synthesis and applications. Carbon 2016, 107, 448-473. [CrossRef]

28. Adachi, T.; Kaida, Y.; Kitazumi, Y.; Shirai, O.; Kano, K. Bioelectrocatalytic performance of D-fructose dehydrogenase. Bioelectrochemistry 2019, 129, 1-9. [CrossRef]

29. Kawai, S.; Goda-Tsutsumi, M.; Yakushi, T.; Kano, K.; Matsushita, K. Heterologous overexpression and characterization of a flavoprotein-cytochrome $c$ complex fructose dehydrogenase of Gluconobacter japonicus NBRC3260. Appl. Environ. Microbiol. 2013, 79, 1654-1660. [CrossRef]

30. Tsujimura, S.; Nishina, A.; Hamano, Y.; Kano, K.; Shiraishi, S. Electrochemical reaction of fructose dehydrogenase on carbon cryogel electrodes with controlled pore sizes. Electrochem. Commun. 2010, 12, 446-449. [CrossRef]

31. Xia, H.-Q.; Hibino, Y.; Kitazumi, Y.; Shirai, O.; Kano, K. Interaction between D-fructose dehydrogenase and methoxy-substituent-functionalized carbon surface to increase productive orientations. Electrochim. Acta 2016, 218, 41-46. [CrossRef]

32. Kawai, S.; Yakushi, T.; Matsushita, K.; Kitazumi, Y.; Shirai, O.; Kano, K. The electron transfer pathway in direct electrochemical communication of fructose dehydrogenase with electrodes. Electrochem. Commun. 2014, 38, 28-31. [CrossRef]

33. Funabashi, H.; Murata, K.; Tsujimura, S. Effect of pore size of MgO-templated carbon on the direct electrochemistry of d-fructose dehydrogenase. Electrochemistry 2015, 83, 372-375. [CrossRef]

34. Kamitaka, Y.; Tsujimura, S.; Kataoka, K.; Sakurai, T.; Ikeda, T.; Kano, K. Effect of axial ligand mutation of the type I copper site in bilirubin oxidase on direct electron transfer-type bioelectrocatalytic reduction of dioxygen. J. Electroanal. Chem. 2007, 601, 119-124. [CrossRef]

35. Lalaoui, N.; Le Goff, A.; Holzinger, M.; Consier, S. Fully oriented bilirubin oxidase on porphyrin functionalized carbon nanotube electrodes for electrocatalytic oxygen reduction. Chem. Eur. J. 2015, 21, 16868-16873. [CrossRef] [PubMed] 
36. Tsujimura, S.; Oyama, M.; Funabashi, H.; Ishii, S. Effects of pore size and surface properties of MgO-templated carbon on the performance of bilirubin oxidase-modified oxygen reduction reaction cathode. Electrochim. Acta 2019, 322, 134744. [CrossRef]

37. Sugimoto, Y.; Kitazumi, Y.; Shirai, O.; Kano, K. Effects of mesoporous structures on direct electron transfer-type bioelectrocatalysis: Facts and simulation on a three-dimensional model of random orientation of enzymes. Electrochemistry 2017, 85, 82-87. [CrossRef]

38. Funabashi, H.; Takeuchi, S.; Tsujimura, S. Hierarchical meso/macro-porous carbon fabricated from dual MgO templates for direct electron transfer enzymatic electrodes. Sci. Rep. 2017, 7, 45147. [CrossRef] [PubMed]

39. Vincent, K.A.; Parkin, A.; Armstrong, F.A. Investigating and exploiting the electrocatalytic properties of hydrogenases. Chem. Rev. 2007, 107, 4366-4413. [CrossRef] [PubMed]

40. Lojou, E. Hydrogenases as catalysts for fuel cells: Strategies for efficient immobilization at electrode interfaces. Electrochim. Acta 2011, 56, 10385-10397. [CrossRef]

41. Mazurenko, I.; Clement, R.; Byrne-Kodjabachian, D.; de Poulpiquest, A.; Tsujimura, S.; Lojou, E. Pore size effect of $\mathrm{MgO}$-templated carbon on enzymatic $\mathrm{H}_{2}$ oxidation by the hyperthermophilic hydrogenase from Aquifex aeolicus. J. Electroanal. Chem. 2018, 812, 221-226. [CrossRef]

42. Alonso-Lomillo, M.A.; Rüdiger, O.; Maroto-Valiente, A.; Velez, M.; Rodríguez-Ramos, I.; Muñoz, F.J.; Fernández, V.M.; De Lacey, A.L. Hydrogenase-coated carbon nanotubes for efficient $\mathrm{H}_{2}$ oxidation. Nano Lett. 2007, 7, 1603-1608. [CrossRef]

43. Fujieda, N.; Tsuse, N.; Satoh, A.; Ikeda, T.; Kano, K. Production of completely flavinylated histamine dehydrogenase, unique covalently bound flavin andiron-sulfur cluster containing enzyme of Nocardioides simplex in Escherichia coli, and its properties. Biosci. Biotechnol. Biochem. 2005, 69, 2459-2462. [CrossRef]

44. Reed, T.; Lushington, G.H.; Xia, Y.; Hirakawa, H.; Travis, D.M.; Mure, M.; Scott, E.E.; Limburg, J. Crystal structure of hystamine dehydrogenase from Nocardioides simplex. J. Biol. Chem. 2010, 285, 25782-25791. [CrossRef] [PubMed]

45. Tsutsumi, M.; Tsujimura, S.; Shirai, O.; Kano, K. Direct electrochemistry of histamine dehydrogenase from Nocardioides simplex. J. Electroanal. Chem. 2009, 625, 144-148. [CrossRef]

46. Park, J.; Joo, J.; Kwon, S.G.; Jang, Y.; Hyeon, T. Synthesis of monodisperse spherical nanocrystals. Angew. Chem. Int. Ed. 2007, 46, 4630-4660. [CrossRef] [PubMed]

47. Peng, S.; Lee, Y.; Wang, C.; Yin, H.; Dai, S.; Sun, S. A facile synthesis of monodisperse Au nanoparticles and their catalysis of oxidation. Nano Res. 2008, 1, 229-234. [CrossRef]

48. Takahashi, Y.; Wanibuchi, M.; Kitazumi, Y.; Shirai, O.; Kano, K. Improved direct electron transfer-type bioelectrocatalysis of bilirubin oxidase using porous gold electrodes. J. Electroanal. Chem. 2019, 843, 47-53. [CrossRef]

49. Gutiérrez-Sánchez, C.; Pita, M.; Vaz-Domínguez, C.; Shleev, S.; De Lacey, A.L. Gold nanoparticles as electronic bridges for laccase-based biocathodes. J. Am. Chem. Soc. 2012, 134, 17212-17220. [CrossRef]

50. Takahashi, Y.; Kitazumi, Y.; Shirai, O.; Kano, K. Improved direct electron transfer-type bioelectrocatalysis of bilirubin oxidase using thiol-modified gold nanoparticles on mesoporous carbon electrode. J. Electroanal. Chem. 2019, 832, 158-164. [CrossRef]

51. Monsalve, K.; Roger, M.; Gutierrez-Sanchez, C.; Ilbert, M.; Nitsche, S.; Byrne-Kodjabachian, D.; Marchi, V.; Lojou, E. Hydrogen bioelectrooxidation on gold nanoparticle-based electrodes modified by Aquifex aeolicus hydrogenase: Application to hydrogen/oxygen enzymatic biofuel cells. Bioelectrochemistry 2015, 106, 47-55. [CrossRef]

52. Pankratov, D.; Sundberg, R.; Suyatin, D.B.; Sotres, J.; Barrantes, A.; Ruzgas, T.; Maximov, I.; Montelius, L.; Shleev, S. The influence of nanoparticles on enzymatic bioelectrocatalysis. RSC Adv. 2014, 4, 38164-38168. [CrossRef]

53. Siepenkoetter, T.; Salaj-Kosla, U.; Xiao, X.; Belochapkine, S.; Magner, E. Nanoporous gold electrode with tuneable pore sizes for bioelectrochemical applications. Electroanalysis 2016, 28, 2415-2423. [CrossRef]

54. Cracknell, J.A.; McNamera, T.P.; Lowe, E.D.; Blanford, C.F. Bilirubin oxidase from Myrothecium verrucaria: $X$-ray determination of the complete crystal structure and a rational surface modification for enhanced electrocatalytic $\mathrm{O}_{2}$ reduction. Dalton Trans. 2011, 40, 6668-6675. [CrossRef] [PubMed]

55. Mizutani, K.; Toyoda, M.; Sagara, K.; Takahashi, N.; Sato, A.; Kamitaka, Y.; Tsujimura, S.; Nakanishi, Y.; Sugiura, T.; Yamaguchi, S.; et al. X-ray analysis of bilirubin oxidase from Myrothecium verrucaria at $2.3 \AA$ resolution using a twinned crystal. Acta Cryst. 2010, F66, 765-770. 
56. Siepenkoetter, T.; Salaj-Kosla, U.; Magner, E. The immobilization of fructose dehydrogenase on nanoporous gold electrodes for the detection of fructose. ChemElectroChem 2017, 4, 905-912. [CrossRef]

57. Hibino, Y.; Kawai, S.; Kitazumi, Y.; Shirai, O.; Kano, K. Mutation of heme $c$ axial ligands in D-fructose dehydrogenase for investigation of electron transfer pathways and reduction of overpotential in direct electron transfer-type bioelectrocatalysis. Electrochem. Commun. 2016, 67, 43-46. [CrossRef]

58. Hibino, Y.; Kawai, S.; Kitazumi, Y.; Shirai, O.; Kano, K. Construction of a protein-engineered variant of D-fructose dehydrogenase for direct electron transfer-type bioelectrocatalysis. Electrochem. Commun. 2017, 77, 112-115. [CrossRef]

59. Hibino, Y.; Kawai, S.; Kitazumi, Y.; Shirai, O.; Kano, K. Protein-engineering improvement of direct electron transfer-type bioelectrocatalytic properties of D-fructose dehydrogenase. Electrochemistry 2019, 87, 47-51. [CrossRef]

60. Kaida, Y.; Hibino, Y.; Kitazumi, Y.; Shirai, O.; Kano, K. Ultimate downsizing of D-fructose dehydrogenase for improving the performance of direct electron transfer-type bioelectrocatalysis. Electrochem. Commun. 2019, 98, 101-105. [CrossRef]

61. Tsuya, T.; Ferri, S.; Fujikawa, M.; Yamaoka, H.; Sode, K. Cloning and functional expression of glucose dehydrogenase complex of Burkholderia cepacia in Escherichia coli. J. Biotechnol. 2006, 123, 127-136. [CrossRef]

62. Okuda-Shimazaki, J.; Loew, N.; Hirose, N.; Kojima, K.; Mori, K.; Tsugawa, W.; Sode, K. Construction and characterization of flavin adenine dinucleotide glucose dehydrogenase complex harboring a truncated electron transfer subunit. Electrochim. Acta 2018, 277, 276-286. [CrossRef]

63. Yamashita, Y.; Ferri, S.; Huynh, M.L.; Shimizu, H.; Yamaoka, H.; Sode, K. Direct electron transfer type disposable sensor strip for glucose sensing employing an engineered FAD glucose dehydrogenase. Enzyme Microb. Technol. 2013, 52, 123-128. [CrossRef]

64. Yamazaki, T.; Okuda-Shimazaki, J.; Sakata, C.; Tsuya, T.; Sode, K. Construction and characterization of direct electron transfer-type continuous glucose monitoring system employing thermostable glucose dehydrogenase complex. Anal. Lett. 2008, 41, 2363-2373. [CrossRef]

65. Kakehi, N.; Yamazaki, T.; Tsugawa, W.; Sode, K. A novel wireless glucose sensor employing direct electron transfer principle based enzyme fuel cell. Biosens. Bioelectron. 2007, 22, 2250-2255. [CrossRef] [PubMed]

66. Lee, I.; Loew, N.; Tsugawa, W.; Lin, C.; Probst, D.; La Belle, J.T.; Sode, K. The electrochemical behavior of a FAD dependent glucose dehydrogenase with direct electron transfer subunit by immobilization on self-assembled monolayers. Bioelectrochemistry 2017, 121, 1-6. [CrossRef] [PubMed]

67. Yamaoka, H.; Ferri, S.; Fujikawa, M.; Sode, K. Essential role of the small subunit of thermostable glucose dehydrogenase from Burkholderia cepacia. Biotechnol. Lett. 2004, 26, 1757-1761. [CrossRef] [PubMed]

68. Shiota, M.; Yamazaki, T.; Yoshimatsu, K.; Kojima, K.; Tsugawa, W.; Ferri, S.; Sode, K. An Fe-S cluster in the conserved Cys-rich region in the catalytic subunit of FAD-dependent dehydrogenase complexes. Bioelectrochemistry 2016, 112, 178-183. [CrossRef]

69. Yamashita, Y.; Suzuki, N.; Hirose, N.; Kojima, K.; Tsugawa, W. Mutagenesis study of the cytochrome $c$ subunit responsible for the direct electron transfer-type catalytic activity of FAD-dependent glucose dehydrogenase. Int. J. Mol. Sci. 2018, 19, 931. [CrossRef]

70. Yamaoka, H.; Yamashita, Y.; Ferri, S.; Sode, K. Site directed mutagenesis studies of FAD-dependent glucose dehydrogenase catalytic subunit of Burkholderia cepacia. Biotechnol. Lett. 2008, 30, 1967-1972. [CrossRef]

71. Bollella, P.; Ludwig, R.; Gorton, L. Cellobiose dehydrogenase: Insights on the nanostructuration of electrodes forimproved development of biosensors and biofuel cells. Appl. Mater. Today 2017, 9, 319-332. [CrossRef]

72. Okuda, J.; Sode, K. PQQ glucose dehydrogenase with novel electron transfer ability. Biochem. Biophys. Res. Commun. 2004, 314, 793-797. [CrossRef]

73. Algov, I.; Grushka, J.; Zarivach, R.; Alfonta, L. Highly efficient flavin-adenine dinucleotide glucose dehydrogenase fused to a minimal cytochrome c domain. J. Am. Chem. Soc. 2017, 139, 17217-17220. [CrossRef] [PubMed]

74. Ito, K.; Okuda-Shimazaki, J.; Mori, K.; Kojima, K.; Tsygawa, W.; Ikebukuro, K.; Lin, C.-E.; Belle, J.L.; Yoshida, H.; Sode, K. Designer fungus FAD glucose dehydrogenase capable of direct electron transfer. Biosens. Bioelectron. 2019, 123, 114-123. [CrossRef] [PubMed]

75. Gilardi, G.; Meharenna, Y.T.; Tsotsou, G.E.; Sadeghi, S.J.; Fairhead, M.; Giannini, S. Molecular Lego: Design of molecular assemblies of P450 enzymes for nanobiotechnology. Biosens. Bioelectron. 2002, 17, 133-145. [CrossRef] 
76. Yuhashi, N.; Tomiyama, M.; Okuda, J.; Igarashi, S.; Ikebukuro, K.; Sode, K. Development of a novel glucose enzyme fuel cell system employing protein engineered PQQ glucose dehydrogenase. Biosens. Bioelectron. 2005, 20, 2145-2150. [CrossRef] [PubMed]

77. Tanaka, S.; Igarashi, S.; Ferri, S.; Sode, K. Increasing stability of water-soluble PQQ glucose dehydrogenase by increasing hydrophobic interaction at dimeric interface. BMC Biochem. 2005, 6, 1. [CrossRef]

78. Pereira, A.R.; Luz, R.A.S.; Lima, F.C.D.A.; Crespilho, F.N. Protein oligomerization based on brønsted acid reaction. ACS Catal. 2017, 7, 3082-3088. [CrossRef]

79. Holland, J.T.; Lau, C.; Brozik, S.; Atanassov, P.; Banta, S. Engineering of glucose oxidase for direct electron transfer via site-specific gold nanoparticle conjugation. J. Am. Chem. Soc. 2011, 133, 19262-19265. [CrossRef]

80. Ferapontova, E.; Schmengler, K.; Börchers, T.; Ruzgas, T.; Gorton, L. Effect of cysteine mutations on direct electron transfer of horseradish peroxidase on gold. Biosens. Bioelectron. 2002, 17, 953-963. [CrossRef]

81. Güven, G.; Prodanovic, R.; Schwaneberg, U. Protein engineering-an option for enzymatic biofuel cell design. Electroanalysis 2010, 22, 765-775. [CrossRef]

82. Eijsink, V.G.H.; Gaseidnes, S.; Borchert, T.V.; van den Burg, B. Directed evolution of enzyme stability. Biomol. Eng. 2005, 22, 21-30. [CrossRef]

83. Wong, T.S.; Schwaneberg, U. Protein engineering in bioelectrocatalysis. Curr. Opin. Biotechnol. 2003, 14, 590-596. [CrossRef]

84. Mate, D.M.; Gonzalez-Perez, D.; Falk, M.; Kittl, R.; Pita, M.; De Lacey, A.L.; Ludwig, R.; Shleev, S.; Alcalde, M. Blood tolerant laccase by directed evolution. Chem. Biol. 2013, 20, 223-231. [CrossRef] [PubMed]

85. Marcus, R.A.; Sutin, N. Electron transfers in chemistry and biology. Biochim. Biophys. Acta 1985, 811, $265-322$. [CrossRef]

86. Dementin, S.; Burlat, B.; Fourmond, V.; Leroux, F.; Liebgott, P.-P.; Hamdan, A.A.; Leger, C.; Rousset, M.; Guigliarelli, B.; Bertrand, P. Rates of intra-and intermolecular electron transfers in hydrogenase deduced from steady-state activity measurements. J. Am. Chem. Soc. 2011, 133, 10211-10221. [CrossRef] [PubMed]

87. Lauterbach, L.; Idris, Z.; Vincent, K.A.; Lenz, O. Catalytic properties of the isolated diaphorase fragment of the $\mathrm{NAD}^{+}$-reducing [NiFe]-hydrogenase from Ralstonia eutropha. PLoS ONE 2011, 6, e25939. [CrossRef] [PubMed]

88. Horch, M.; Lauterbach, L.; Lenz, O.; Hildebrandt, P.; Zebger, I. NAD(H)-coupled hydrogen cycling-structure-function relationships of bidirectional [NiFe] hydrogenases. FEBS Lett. 2012, 586, 545-556. [CrossRef] [PubMed]

89. Sakai, K.; Kitazumi, Y.; Shirai, O.; Takagi, K.; Kano, K. Direct electron transfer-type four-way bioelectrocatalysis of $\mathrm{CO}_{2}$ /formate and $\mathrm{NAD}^{+} / \mathrm{NADH}$ redox couples by tungsten-containing formate dehydrogenase adsorbed on gold nanoparticle-embedded mesoporous carbon electrodes modified with 4-mercaptopyridine. Electrochem. Commun. 2017, 84, 75-79. [CrossRef]

90. Reda, T.; Plugge, C.M.; Abram, N.J.; Hirst, J. Reversible interconversion of carbon dioxide and formate by an electroactive enzyme. Proc. Natl. Acad. Sci. USA 2008, 105, 10654-10658. [CrossRef]

91. Bassegoda, A.; Madden, C.; Wakerley, D.W.; Reisner, E.; Hirst, J. Reversible interconversion of $\mathrm{CO}_{2}$ and formate by a molybdenum-containing formate dehydrogenase. J. Am. Chem. Soc. 2014, 136, 15473-15476. [CrossRef]

92. Hori, Y.; Vayenas, C.G.; White, R.E.; Gamboa-Aldeco, M.E. Modern Aspects of Electrochemistry; Springer: Berlin/Heidelberg, Germany, 2008.

93. Adachi, T.; Kitazumi, Y.; Shirai, O.; Kano, K. Construction of a bioelectrochemical formate generating system from carbon dioxide and dihydrogen. Electrochem. Commun. 2018, 97, 73-76. [CrossRef]

94. Siritanaratkul, B.; Megarity, C.F.; Roberts, T.G.; Samuels, T.O.M.; Winkler, M.; Warner, J.H.; Happe, T.; Armstrong, F.A. Transfer of photosynthetic $\mathrm{NADP}^{+} / \mathrm{NADPH}$ recycling activity to a porous metal oxide for highly specific, electrochemically-driven organic synthesis. Chem. Sci. 2017, 8, 4579-4586. [CrossRef]

95. Wan, L.; Megarity, C.F.; Siritanaratkul, B.; Armstrong, F.A. A hydrogen fuel cell for rapid, enzyme-catalysed organic synthesis with continuous monitoring. Chem. Commun. 2018, 54, 972-975. [CrossRef] [PubMed] 